\title{
WPS3801
}

\section{Neither a Borrower Nor a Lender: Does China's Zero Net Foreign Asset Position Make Economic Sense?}

\author{
David Dollar and Aart Kraay \\ The World Bank
}

\begin{abstract}
China in the past few years has emerged as a net foreign creditor on the international scene with net foreign assets slightly greater than zero percent of wealth. This is surprising given that China is a relatively poor country with a capital-labor ratio about one-fifth the world average and one-tenth the U.S. level. The main questions that we address are whether it makes economic sense for China to be a net creditor and how we see China's net foreign asset position evolving over the next 20 years. We calibrate a theoretical model of international capital flows featuring diminishing returns, production risk, and sovereign risk. Our calibrations for China yield a predicted net foreign asset position of -17 percent of China's wealth. We also estimate non-structural cross-country regressions of determinants of net foreign assets in which China is always a significant outlier with 5 to 7 percentage points more of net foreign assets relative to wealth than is predicted by its characteristics. China's extensive capital controls can explain why its current net foreign asset position is far away from what is predicted by open-economy models and cross-country empirics. It seems reasonable to assume that China's international financial integration will increase over time. We calibrate and predict different scenarios out to 2025 . These scenarios are necessarily speculative, but it is interesting that they typically imply negative net foreign asset positions between 3 and 9 percent of wealth. What may be counter-intuitive for many policy-makers is that successful institutional reform and productivity growth are likely to lead to more negative net foreign asset positions than occurs with stagnation. Starting from China's zero net foreign asset position, it would take current account deficits in the range of 2-5 percent of GDP to reach any of these future net foreign asset positions. These are not unreasonable deficits, but they require a large adjustment from the present 6 percent of GDP current account surplus.
\end{abstract}

\section{World Bank Policy Research Working Paper 3801, December 2005}

The Policy Research Working Paper Series disseminates the findings of work in progress to encourage the exchange of ideas about development issues. An objective of the series is to get the findings out quickly, even if the presentations are less than fully polished. The papers carry the names of the authors and should be cited accordingly. The findings, interpretations, and conclusions expressed in this paper are entirely those of the authors. They do not necessarily represent the view of the World Bank, its Executive Directors, or the countries they represent. Policy Research Working Papers are available online at http://econ.worldbank.org.

1818 H Street N.W., Washington, DC 20433, ddollar@worldbank.org, akraay@worldbank.org. This paper was prepared for the Carnegie-Rochester Conference Series on Public Policy held in Pittsburgh on November 17-18, 2005. We are grateful to conference participants and especially our discussant, Shang-jin Wei, for helpful comments. We also thank Philip Lane and Gian Maria Milesi-Ferretti for sharing their preliminary estimates of China's net foreign asset position through 2003; Natalia Tamirisa for sharing her data on capital controls; and Xiaofan Liu for her help with Chinese statistics. 


\section{Introduction}

China in the past few years has emerged as a net creditor on the international scene. This development is surprising given that China is still a relatively poor country with per capita GDP of $\$ 5000$ in 1996 PPP terms and a capital-labor labor ratio about one-fifth the world average and one-tenth the U.S. level. Neoclassical theory suggests that the return to capital in China should be relatively high and that in an increasingly integrated world economy the rest of the world should be a net lender to China rather than a net borrower from it. There are plenty of institutional weaknesses and distortions that can keep the return to capital in developing countries low, despite a low capital-labor ratio, but anecdotal evidence suggests that the return to much of the investment in China is quite high. Certainly the typical Fortune 500 company finds China more attractive than most other developing countries.

The main question that we address then is whether it makes economic sense for China to be a net creditor. Or, more generally, what is the expected net foreign asset position of China given its productivity level, its stock of capital, and its population, relative to the rest of the world? We are interested in answering this question in light of the most recent data. But an even more interesting question is what we expect China's net foreign asset position to be in 15 to 20 years. It is likely that market reforms including financial liberalization and opening of the capital account - will continue and that by 2025 China will be well integrated into the global economy. There are many reasons why the current net foreign asset position of China may be distorted away from an economically rational position, but it is likely that by 2025 most of the restrictions on the capital account will be gone. If we have a good sense of what China's net foreign asset position will be in 15 to 20 years, then we have a good sense of what the pattern of current account balances will be over this period. Naturally, projecting ahead 15 to 20 years is highly speculative, but we think that exploring several different scenarios enables us to trace out a number of plausible adjustment paths for the current account.

The question that we address should be of interest to economists and policymakers for a number of reasons. China is the second largest economy in the world in PPP terms and the third largest trading nation. By 2025 it is likely to emerge as the largest trading nation. Hence whether China is a net supplier of capital to the rest of the 
world (with a trade surplus) or a net borrower (with a trade deficit) will have a significant effect on global macroeconomic balances as well as on the volume and patterns of trade. We do not contribute to the (sometimes heated) debate about the current Chinese trade balance and exchange rate policy. But our analysis does relate to the exchange rate issue in the long run. Whether China's current account is likely to remain in significant surplus or shift to a deficit will naturally affect the equilibrium exchange rate (and in fact our analysis can be combined with other empirical analyses of the relationship between the exchange rate and the trade balance to form a view on future directions of the exchange rate).

The remainder of the paper is organized as follows: in Section 2 we introduce some basic stylized facts about China's saving, current account, and net foreign asset position. It is well known that China has a high savings rate, reaching $50 \%$ of GDP in 2004. In light of this high savings rate it may not seem so surprising that in recent years China has had a current account surplus (excess of savings over investment). But introducing the data on the stock of foreign assets and liabilities highlights our puzzle: China has recently shifted to being a net creditor to the rest of the world, and that position is highly unusual for a poor country whose capital-labor ratio is well below the world average.

In Section 3 we draw on the model of North-South capital flows of Kraay, Loayza, Serven, and Ventura (2005) to develop a theoretical expectation of what China's net foreign asset position should look like. In the model diminishing returns and production risk provide motives for cross border capital flows. In fact, these factors alone suggest very large capital flows - far beyond what is observed empirically. But introducing a realistic amount of concern about international default, based on historical experience, results in equilibrium net foreign asset positions close to what is observed in the data. In this model, a country's net foreign asset position will depend on its per capita wealth and its productivity level relative to the rest of the world. We calibrate the model with the current Chinese data and examine China's expected net foreign asset position. Our baseline calibration predicts that China should have a net foreign asset position of negative 17 percent of its wealth, in contrast to the small positive position that it has in reality. We show how sensitive this result is to reasonable changes in key parameters. 
In Section 4 we complement this analysis with a non-structural empirical investigation using a cross section of 62 countries. In practice net foreign assets can be predicted fairly well based on a country's wealth, population, and a measure of institutional quality that we take as an underlying determinant of productivity. Net foreign asset positions are positively related to wealth per capita and, controlling for that, negatively related to institutional quality. In particular, developing countries with better institutional quality (higher productivity) attract more capital inflows and retain more of their own people's savings. In this empirical implementation, China is a large outlier, with a more positive net foreign asset position than would be predicted by its characteristics. That finding is consistent with the calibration result.

In Section 5 we then use the calibration and empirical models to investigate a number of plausible scenarios for the future. There are certainly different directions in which China's economy could go, and quite a large existing literature with different views on just how significant productivity growth has been during China's reform. One plausible scenario is that economic reform continues, including the shift from state to private ownership and deepening of financial sector reform. We draw on recent empirical analyses of productivity growth in Chinese industry that find significant productivity growth resulting in part from reallocation from state to private as well as significant further scope for this reallocation: for example, nearly two-thirds of the industrial capital stock is still under state control. This high reform scenario we model as continued improvement in China's productivity relative to the rest of the world together with some moderation of the very high savings rates of recent years. Improvements in consumer finance, pension instruments, and health insurance should enable Chinese households to save less and increase welfare. The high reform scenario suggests that China will emerge by 2025 as a significant net debtor, and that a linear path of current account balances to achieve this would result in average deficits in the 5\% of GDP range.

The opposite of the high reform scenario is a situation in which reforms stagnate or backtrack, with little further productivity gain relative to the rest of the world and continued high savings in the face of poorly functioning pension and health insurance systems. In this calibration China emerges as a smaller net debtor in 2025 . One of our important findings, which may be counter-intuitive to some policy-makers, is that 
successful institutional development and productivity growth in China should be accompanied by larger current account deficits. Ongoing smaller current account surpluses or even small surpluses, on the other hand, would be consistent with stalled development in which Chinese people, despite their relative poverty, choose to move assets abroad.

Any calibration exercise needs to be taken with some caution, and we have tried to show different plausible scenarios to emphasize the uncertainties. But we think that two important points should be taken from this analysis. First, it is difficult to find any plausible scenario in which it makes sense for China to have significant current account surpluses stretching into the future. As a capital-scarce country that has achieved quite a good productivity level and return to capital, it does not make sense for China to be a large net supplier of capital to the rest of the world over the next two decades. Second, if China continues its market reforms, it is likely that productivity levels will continue to increase while its extraordinarily high savings rate will decline. In this plausible scenario, there could well be large net inflows of capital into China as investors worldwide try to move some of their portfolio into this attractive location. Starting from the present current account surplus of about $6 \%$ of GDP, this would require a large swing in the trade balance and probably a significant appreciation of the exchange rate. As China continues to liberalize its financial system and capital account, managing this adjustment will be a serious challenge.

\section{Background: Saving, the Current Account and Net Foreign Assets in China}

Both savings and investment rates are relatively high in China compared to other countries, and there has been a general trend for both to increase during the reform period, from about $35 \%$ of GDP in the 1980 s to above $45 \%$ in recent years (Figure 1). In the early period of reform investment grew more rapidly than savings and China developed a current account deficit reaching 4\% of GDP in 1985 (Figure 2). The late 1980s saw a period of overheating followed by a sharp drop in investment rates. With the savings rate gradually rising, the current account swung to a surplus of $4 \%$ of GDP by 1991 . Since 1990 there has been only one year (1993) in which China did not have a current account surplus. Note that the trade balance tracked the current account very closely up to 1994 , as there was little in the way of net factor payments during the early 
reform period. Between 1995 and 2002 China tended to make net factor payments to the rest of the world equal to about 1\% of GDP, so that the current account surplus was generally lower than the trade surplus. In 2004, however, China switched to being a net recipient of factor payments from abroad so that the current account is now larger than the trade balance.

To come up with an estimate of the total wealth in place in China we begin by cumulating investment to arrive at an estimate of the capital stock. We use PPP investment rates, which are much lower than non-PPP rates given the high price of capital goods relative to non-capital goods in China. This gives us a growth rate of the capital stock equal to 8.8\% per year between 1980 and 2000. This falls just between official estimates of the non-agricultural capital stock growth rate and alternative estimates provided by Young (2003). To arrive at total wealth we add to the capital stock an estimate of net foreign assets constructed by Lane and Milesi-Ferretti (2001a). ${ }^{1}$ Relative to GDP there were large swings in net foreign assets over the reform period (Figure 3). China went from being a net creditor at the beginning of reform, to a net debtor with NFA totaling $-15 \%$ of GDP by the mid-1990s. The string of current account surpluses since then has brought China to the position of being a net creditor by 2003. Expressed as a share of China's wealth, these swings are much more moderate (Figure 3). China's net foreign liabilities were equivalent to about $3 \%$ of its wealth in the mid1990s; its net creditor position in 2003 was less than $1 \%$ of its wealth at that time.

The composition of capital flows that lies behind these shifts is an interesting one, quite different from the many developing countries that have borrowed heavily on global markets (Figure 4). China's debt liabilities have always roughly mirrored its debt assets. China's limited international borrowing was matched by its own overseas lending (mostly trade credits, loans to other developing countries, and lending in support of Chinese companies abroad). Outward direct investment flows from China have been very small. The significant flows on China's capital account have been inward direct investment and reserve accumulation. The stock of inward FDI relative to China's wealth climbed very sharply after 1990 and reached about 4\% of China's wealth in recent years. Reserve accumulation has largely mirrored this. So, China's essentially

\footnotetext{
${ }^{1}$ We are grateful to Phil Lane and Gian-Maria Milesi-Ferretti for kindly sharing preliminary updates of their estimates for China through 2003.
} 
zero net foreign asset position in the recent period reflects modest and balanced debt flows plus a significant stock of foreign direct investment in the economy that is roughly balanced by reserves accumulated.

The end result is something of an anomaly compared to other countries. In general, net foreign assets relative to wealth rise with the level of development, measured for example by the capital-labor ratio (Figure 5). As one would expect intuitively, countries with low capital-labor ratios are generally net debtors, and ones with high capital-labor ratios are generally net creditors. China is an outlier in this picture; its essentially zero net foreign asset position is unusual for a developing country. There may be reasons why this is an equilibrium outcome, which we will explore in the next two sections. But it is also possible that the current net foreign asset position is far away from an equilibrium, which would be possible if China's capital account controls are largely effective.

The pattern of capital flows that we observe does mirror fairly well the restrictions in China's capital account. There are tight restrictions on any outflows of capital. Both outward direct investment and outward portfolio flows essentially require administrative approvals and are subject to overall targets that are part of China's economic plans and until recently have been set at low levels. On the inward side, portfolio flows are quite restricted. Only inward direct investment has been relatively and increasingly liberalized. More and more sectors and geographic locations have been opened up to FDI over time. Most recently, on April 1, 2002, a new four-tier classification system for foreign investment was introduced, defining activities where foreign investment is encouraged, permitted, restricted, or banned. In effect, this resulted in the opening up of many industries previously closed to foreign investment, particularly in the services sectors, consistent with China's WTO-related commitments. Prasad and Wei (2005) provide a much more detailed description of China's capital inflows and the restrictions to which they are subject.

A final point about reported FDI is that some of it probably belongs to Chinese residents. It is difficult to be precise about the geographic origin of FDI flows. Official figures show almost half as coming from Hong Kong or tax havens. A significant part of such flows presumably comes from third, unidentified, countries, and a substantial part 
of this is Chinese capital that has been recycled through these areas in order to benefit from the advantageous tax treatment offered to foreign-based companies. It is difficult to get a precise estimate of this "round-tripping" FDI, but the highest plausible estimate would be around one-third. Of the remaining identified FDI inflows, two-thirds comes from other Asian countries. Note that Japan, the U.S., and Europe together have not yet been particularly large investors in China, so that the ownership of assets in China by OECD residents is quite small. The existence of "round-tripping" FDI means that our estimate of China's net foreign asset position is likely to be biased downward. We are not going to try to correct formally for this. And in any case, trying to correct for the "round-tripping" FDI only worsens the puzzle of why China's net foreign asset position is more positive than one might expect.

\section{Calibration Evidence on China's Long-Term Foreign Asset Position}

In this subsection we take the model of North-South capital flows of Kraay, Loayza, Serven, and Ventura (2005) (hereafter KLSV) and perform a simple calibration exercise to generate theoretical predictions for China's net foreign asset position. The model has three key ingredients: diminishing returns, production risk, and sovereign risk. As is well understood the first two factors create strong incentives to spread capital across countries. Absent a countervailing force the model predicts very large NorthSouth capital flows, at least an order or magnitude greater than what we observe in reality. The third ingredient of sovereign risk provides the necessary countervailing force required to bring the predictions of the theory closer to the data. An attractive feature of the model is that a small, and empirically reasonable, dose of sovereign risk is enough to generate reasonable predictions for North-South capital flows. We first describe the model, and then explain how we calibrate the model to generate predictions for China's net foreign asset position.

\section{A Model of International Capital Flows}

We begin by briefly describing the KLSV model of international capital flows, and refer the reader to the original paper for details. The world consists of two countries labeled North and South. We will interpret the latter as China and the former as the rest of the world. There is one factor of production, capital; and a single numeraire good 
that can be used for consumption and investment. KLSV normalize world population to one and assume that a fraction $\eta$ lives in North. Both countries contain a continuum of identical consumer/investors with the following preferences:

$$
E \int_{0}^{\infty} \ln c(t) \cdot e^{-\delta \cdot t} \cdot d t
$$

where $\mathrm{c}$ is consumption. Throughout, variables without asterisks refer to North and variables with asterisks refer to South.

Let $\mathrm{k}$ and $\mathrm{k}^{\star}$ be the capital stocks located in North and South. To produce one unit of capital, one unit of the consumption good is required. Since capital is reversible, the price of each unit is always one and its return is the flow of production net of depreciation. Let $\omega$ and $\omega^{\star}$ be two standard Wiener processes with independent increments with $E[d \omega]=E\left[d \omega^{*}\right]=0, E\left[d \omega^{2}\right]=E\left[d \omega^{*}\right]=d t$ and $E\left[d \omega \cdot d \omega^{*}\right]=0$. The flow of production net of depreciation is given by $R \cdot d t+V \cdot d \omega$ in North and $R^{*} \cdot d t+V^{*} \cdot d \omega^{*}$ in South; where $R$ and $R^{\star}$ are shorthand for $R=\pi \cdot\left(\frac{k}{\eta}\right)^{-\gamma}$ and $R^{*}=\left(\frac{k^{*}}{1-\eta}\right)^{-\gamma}(0 \leq \gamma \leq 1)$, and $V$ and $\mathrm{V}^{*}$ are shorthand for $\mathrm{V}=\frac{\sigma}{\sqrt{\eta}}$ and $\mathrm{V}^{*}=\frac{\phi \cdot \sigma}{\sqrt{1-\eta}}$ with $\sigma \geq 0$. This formulation assumes that the mean and variance of the return to capital are independent of the size of the population. The parameter $\pi$ is a measure of the technological advantage of North relative to South. The parameter $\gamma$ measures the strength of diminishing returns which, for simplicity, are treated as an externality or congestion effect. The parameter $\sigma$ measures the importance of country-specific production risk. The parameter $\phi>1$ measures the extent to which the production risk is higher in South than in North.

KLSV assume that North (South) residents own and operate all the capital stock that is located in North (South). There is a financial market in which only risk-free bonds and claims on North and South production are traded. Risk-free bonds have a price of one and promise an instantaneous interest rate r.dt. Claims to North (South) production have a price $v\left(v^{*}\right)$ and promise to pay the net flow of production generated by one unit 
of North (South) capital. We refer to the holdings of risk-free bonds and claims to overseas production as foreign loans and foreign investments, respectively.

Foreign loans and foreign investments will be used in equilibrium if and only if the probability they are honored is high enough. It is also evident that enforcing contracts sometimes requires the threat of force. These observations raise a familiar timeinconsistency problem. Since governments cannot punish foreign citizens, international financial transactions crucially rely on governments' willingness to punish their own citizens if they default on their obligations towards foreigners. All governments would like to commit to punish default 'ex-ante', since this would allow domestic investors to exploit beneficial trade opportunities. But this commitment might not always be credible, since governments might not have an incentive to punish default 'ex-post'. It is this lack of credibility that creates sovereign risk, and its key implication is that beneficial trade opportunities are left unexploited for fear of default.

KLSV model the decision to punish default as a rational decision of the government. Let $s=\{0,1\}$ be the state of the world. During 'normal times' $(s=0)$ both countries can credibly commit to punish their citizens who default with penalties that are large enough to discourage default. As a result, if $s=0$ no country defaults. During 'crisis periods' ( $s=1$ ) countries cannot credibly commit to imposing penalties in the case of default that go beyond retaliation in kind. As a result, if $s=1$ the country with a negative net foreign asset position defaults. Let $\alpha \cdot d t$ and $\beta \cdot d t$ be the probabilities that the world transitions from $s=0$ to $s=1$ and vice versa; and assume these transitions are independent of production shocks, i.e. $E[d \omega \cdot d s]=E\left[d \omega^{*} \cdot d s\right]=0$. The value of $d s$ is revealed after countries have chosen their portfolios. As a result, the probability of default is $1-\beta \cdot d t$ if $s=0$ and $\alpha \cdot d t$ if $s=1$. The world economy therefore exhibits periods of trade in assets that culminate in crises ( $s$ transitions from $s=0$ to $s=1$ ) in which the debtor country defaults. After this happens, a crisis period ensues in which there is no trade in assets. Eventually, international trade in assets resumes ( $s$ transitions from $s=1$ to $s=0$ ) and the cycle starts again. ${ }^{2}$

\footnotetext{
${ }^{2}$ A key assumption here is that no value is destroyed in the case of default: ownship of assets transfers from the defaultee to the defaulter with no loss of value. KLSV also consider the case where default is costly and a portion of capital is destroyed in the process of default. In addition to being realistic, this assumption helps to explain the empirical fact that net foreign asset positions tend to be financed more by debt rather than equity. We do not consider this extension
} 
In normal times there is trade in assets and we can write North's budget constraint as follows:

$$
\begin{aligned}
d a & =\left(\frac{R \cdot(k-e)+R * \cdot e^{*}+r \cdot I}{\eta}-c\right) \cdot d t+V \cdot\left(\frac{k-e}{\eta}\right) \cdot d \omega+V * \cdot \frac{e^{*}}{\eta} \cdot d \omega * \\
& +\left(\frac{v \cdot e-v^{*} \cdot e^{*}-I}{\eta}\right) \cdot d s
\end{aligned}
$$

where $a$ is the per capita wealth of North; e and $e^{*}$ are the number of foreign investments in North and South; and I is the number of foreign loans issued by North and owed by South. Naturally, the following restriction applies:

$$
\eta \cdot a=k-v \cdot e+v * \cdot e *+1
$$

This budget constraint shows how the expected return and volatility of wealth depend on portfolio decisions. The only novelty relative is the presence of a third term describing the wealth shock that the investor experiences at the onset of a crisis period. As a result of default, all foreign obligations are forfeited and the country loses/gains its net foreign asset position. During crisis periods there is no trade in assets and we must impose the additional restriction that $\mathrm{e}^{\mathrm{e}} \mathrm{e}^{\star}=\mathrm{I}=0$. Throughout, we rule out Ponzi schemes and impose short-sale constraints on foreign investments, i.e. $e \geq 0$ and $e^{\star} \geq 0$.

To determine the optimal consumption and portfolio rules, the representative consumer in North maximizes (1) subject to (2), (3), and the dynamics of asset prices and their return characteristics, i.e. the laws of motion of $r, v, v^{*}, R$ and $R^{\star}$. Since the representative consumer is infinitesimal, he/she understands that his/her actions have no influence on these prices and their evolution. Appendix 2 of KLSV shows that the first-order conditions associated with this problem can be written as follows:

of the theory here as we are primarily interested in the implications of the theory for China's overall net foreign asset position, and not its financing. We also note that KLSV show that adding these default costs does not significantly affect the predictions of the theory for the net foreign asset position, but only for its financing. 


$$
\mathrm{c}=\delta \cdot \mathrm{a}
$$

$$
\mathrm{R}-\rho=\mathrm{V}^{2} \cdot \frac{\mathrm{k}-\mathrm{e}}{\eta \cdot \mathrm{a}}
$$

$$
r-\rho=\alpha \cdot \frac{\eta \cdot a}{k}
$$

$$
\rho \cdot v-R=-V^{2} \cdot \frac{k-e}{\eta \cdot a}-\alpha \cdot \frac{\eta \cdot a}{k} \cdot v
$$

$$
R^{*}-\rho \cdot v^{*} \leq V^{2} \cdot \frac{e^{*}}{\eta \cdot a}+\alpha \cdot \frac{\eta \cdot a}{k} \cdot v^{*} ; \text { with strict ineq. if } e^{*}>0
$$

where $\rho$ is the multiplier associated with constraint (3) divided by the marginal utility of wealth. This quantity can be interpreted as the risk-free rate that applies on loans between North residents. The representative consumer in South maximizes a similar problem resulting in a similar set of first-order conditions.

Equation (4) is the first-order condition associated with c; and shows the familiar result that consumption equals the annualized value of wealth. With logarithmic preferences, the discount factor is equal to the rate of time preference. Equation (5) is the first-order condition associated with $\mathrm{k}$ and captures the premium for holding domestic production risk.. Since there is some probability that foreign obligations are not fulfilled, international transactions also require a sovereign risk premium. Equation (6) pins down this sovereign risk premium, which is increasing in the risk of default. Equation (7) can be interpreted as determining the price at which North is willing to sell claims to its own output to South. Each claim sold by North reduces its income by the flow of production generated by one unit of capital, but now it also provides a gain of one unit of capital in the event of a crisis. Equation (8) defines the demand for foreign investment in the presence of both production and sovereign risk. 
What are the implications of sovereign risk for North-South capital flows? It is straightforward to show that, for a given distribution of capital stocks between North and South, foreign investments and foreign loans are:

$$
\mathrm{e}=\frac{(1-\eta) \cdot \mathrm{a}^{*}}{\eta \cdot \mathrm{a}+(1-\eta) \cdot \mathrm{a}^{*}} \cdot \mathrm{k} ; \quad \mathrm{e}^{*}=\frac{\eta \cdot \mathrm{a}}{\eta \cdot \mathrm{a}+(1-\eta) \cdot \mathrm{a}^{*}} \cdot \mathrm{k}^{*} ; \quad \text { and } \quad \mathrm{I}=0
$$

This result means that, despite the presence of sovereign risk, there is full sharing of production risk, as each country receives a share of world production that is proportional to its share of world wealth. This result might seem counterintuitive at first sight, but the intuition behind it is rather simple. Since countries' only exposure to sovereign risk is their net foreign asset position, countries hedge against this type of risk by holding small net foreign asset positions. This does not preclude countries from hedging against production risk by holding large but roughly balanced gross foreign investment positions.

Sovereign risk does however have important effects on the prices at which North and South are willing to sell claims on their equity. In particular, the prices of foreign investments in North and South are given by: ${ }^{3}$

$$
v=\frac{\rho}{r} \text { and } v^{*}=\frac{\rho^{*}}{r}
$$

Countries are willing to sell claims on their equity to foreigners at a discount reflecting the probability of default. This is because if default occurs, countries will be able to reclaim these investments.

Sovereign risk also reduces international capital flows. To see this, note that the world distribution of capital stocks is implicitly determined by:

$$
r=\pi \cdot\left(\frac{k}{\eta}\right)^{-\gamma}-\sigma^{2} \cdot \frac{k / \eta}{\eta \cdot a+(1-\eta) \cdot a^{*}}+\alpha \cdot\left(\frac{k}{\eta \cdot a}\right)^{-1}
$$

\footnotetext{
${ }^{3}$ This follows from substituting (5) and (6) into (7), and the same for South.
} 


$$
\begin{aligned}
& r=\left(\frac{k}{1-\eta}\right)^{-\gamma}-\sigma^{2} \cdot \phi^{2} \cdot \frac{k * /(1-\eta)}{\eta \cdot a+(1-\eta) \cdot a^{*}}+\alpha \cdot\left(\frac{k *}{(1-\eta) \cdot a}\right)^{-1} \\
& k+k^{*}=\eta \cdot a+(1-\eta) \cdot a^{*}
\end{aligned}
$$

Equations (11) and (12) describe the demand for North and South capital, and Equation (13) is the market-clearing or world adding-up constraint. The demands for capital consist of three terms. The first terms on the right-hand side of Equations (11) and (12) are the respective marginal product of capital. The demand for North capital will be higher (lower) than the demand for South capital if North productivity is higher (lower) than South productivity, i.e. $\pi>1(\pi<1)$. The second term is the risk premium associated with production risk, which is higher in South than in North if the volatility of production is higher in South, i.e. if $\phi>1$. Note that absent asymmetries in productivity and volatility, both North and South would have the same capital stock per capita in equilibrium. The third term captures the effects of sovereign risk. Foreign loans also command a premium to compensate for sovereign risk, and this raises the demand for North capital more than South capital. The reason is that sovereign risk creates a home bias in the demand for capital and North is richer than South. As $\alpha \rightarrow \infty$, we find that the world distribution of capital stocks approaches the world distribution of wealth, i.e. $k \rightarrow \eta \cdot a$ and $k^{*} \rightarrow(1-\eta) \cdot a^{*}$.

\section{Quantitative Implications for China}

We next provide estimates of China's net foreign asset position that come from calibrating this simple model of North-South capital flows. We interpret China as the South, and the rest of the world as North. Since China's accounts for 20 percent of the world's population we set $\eta=0.8$. We next need an estimate of China's share of world wealth. World wealth is equal to the value of the world capital stock, and since China's net foreign asset position as a share of its wealth is very close to zero, China's share in world wealth is equal to the share of its capital stock in the world capital stock. We 
estimate that China's share of the world capital stock as of 2000 is about 8 percent. We choose units such that the world capital stock to one in the theory. We therefore set (1$\eta) \cdot a^{*}=0.08$, or $a=1.15$ and $a^{*}=0.4$ implying that the rest of the world has per capita wealth that is roughly three times higher than in China.

We next calibrate production risk by equating $\mathrm{V}=\frac{\sigma}{\sqrt{\eta}}$ and $\mathrm{V}^{*}=\frac{\phi \cdot \sigma}{\sqrt{1-\eta}}$ with the standard deviation of rest-of-world and Chinese real per capita GDP growth. For this calculation we define the rest of the world as the 98 countries in the PWT6.1 with continuous annual data on real GDP per capita between 1960 and 2000. The standard deviation of real per capita GDP growth for the world excluding China over this period is 1.4 percent, so we set $V=0.014$ which implies $\sigma=0.013$. For China we focus on the post1978 period where the standard deviation of real per capita GDP growth was 3.7. We set $V^{*}=.037$ which implies $\phi=1.32$. For sovereign risk we follow KLSV and set $\alpha=0.03$, who argue that this roughly corresponds to the frequency of episodes of widespread default over the past 150 years.

We also need to calibrate China's relative productivity advantage or disadvantage, $\pi$. We use a very simple cross-country development accounting exercise to retrieve $\pi$ from the data. Assuming a common Cobb-Douglas production function, the ratio of marginal products of two countries is $\frac{A}{A^{*}} \cdot\left(\frac{K / L}{K^{*} / L^{*}}\right)^{\kappa-1}$ where $\kappa$ is the capital share, $A$ and $A^{*}$ are total factor productivity, and $K / L$ and $K * / L *$ are capital stocks per worker. In the theory, the ratio of the expected marginal product of capital in North relative to South is $\pi \cdot\left(\frac{\mathrm{k} / \eta}{\mathrm{k}^{*} /(1-\eta)}\right)^{-\gamma}$. We follow KLSV in setting $\gamma=0.25$, which corresponds to $\kappa=0.75$. This can be justified by interpreting $\mathrm{K}$ as a broad concept of capital. We next retrieve estimates of $A$ and $A^{*}$ as residuals from this production function, setting $\kappa=0.75$. To implement this we use data on GDP and capital stocks per worker for China and for an aggregate of the rest of the world in 1996, which is the year that maximizes our cross-country data coverage. For China, GDP per worker and capital per worker were $\$ 4,908$ and $\$ 7,408$ in 1996 PPP terms. For the rest of the world the corresponding figures are $\$ 17,697$ and $\$ 39,137$ respectively. This implies a relative 
TFP of $A / A^{*}=1.03$, suggesting that TFP levels in China and in an aggregate of the rest of the world are roughly the same. We therefore take $\pi=1$ as our benchmark value.

We are now ready to calibrate the predictions of the model for China's net foreign asset position as a share of its wealth, which is:

$$
n f a *=1-\frac{k^{*}}{(1-\eta) \cdot a^{*}}
$$

For our benchmark parameter values, China's predicted net foreign asset position as a share of wealth is -17 percent of its wealth, which is substantially more negative than its current value of roughly zero percent of wealth. We interpret this discrepancy between the quantitative predictions of the theory as reflecting China's barriers to capital inflows and capital outflows. Absent these distortions, the theory suggests that China's net foreign asset position would be considerably more negative than what we currently observe. It is also useful to note that a net foreign asset position of -17 percent of wealth is not unreasonable when compared with other countries. In the sample of 61 countries underlying Figure 5, the average net foreign asset position is -13 percent of wealth. Finally, we note the important role played by sovereign risk in generating reasonable net foreign asset positions. Absent sovereign risk, and given that we find very small differences in average productivity and volatility between China and ROW, the model would predict that per capita capital stocks would be equalized across countries. This would result in a predicted net foreign asset position equal to -400 percent of China's wealth. Only a modest dose of sovereign risk of $\alpha=0.03$ is enough to bring China's predicted net foreign asset position to a much more reasonable -17 percent of wealth.

Of course, this predicted value is sensitive to our assumptions about the underlying parameters. In Figure 6 we report how our estimates of the NFA position vary with two key parameters underlying the calibration. In the top panel we show how China's NFA position would change with alternative assumptions about the ROW productivity advantage. Not surprisingly, the larger is the ROW productivity advantage, $\pi$, the larger is China's NFA position as capital shifts from China to ROW. The magnitude of this effect is substantial. If ROW had a 20 percent productivity advantage, i.e. $\pi=1.2$, then China's NFA position would increase to -3 percent of wealth. 
Conversely, if China had a 20 percent productivity advantage, i.e. $\pi=1 / 1.2=0.83$, then China's NFA position would be -30 percent of its wealth.

In the bottom panel of Figure 6 we show how our predictions for China's NFA position change with our assumptions regarding China's per capita wealth relative to the rest of the world. Changes in relative wealth are important to consider in the case of China: its per capita wealth relative to the rest of the world has nearly tripled from 11 percent to 31 percent between 1980 and 2000. If China's very high savings rates persist (and this is something we will discuss further in Section 5 of the paper), and also relatively lower savings rates in the rest of the world persist, then China's relative wealth could increase substantially further. This in turn has implications for China's foreign asset position, as shown in the bottom panel of Figure 6. China's net foreign asset position is increasing in wealth. The reason for this is straightforward. Sovereign risk creates a home bias in capital stocks, but this home bias is not complete. Increases in per capita wealth therefore increase the domestic capital stock per capita less than onefor-one. As a result, the net foreign asset position increases with wealth (recall Equation (14), which shows that the net foreign asset position depends negatively on the ratio of the per capita capital stock to per capita wealth). This effect is quantitatively important. For example a further tripling of China's per capita wealth relative to the rest of the world, from 30 percent to 90 percent, would increase its predicted NFA position to just about zero percent of wealth.

The theoretical model we have developed suggests that a reasonable net foreign asset position for China given its current relative productivity and relative wealth would be somewhere around -17 percent of wealth. We have also seen that predictions for China's future net foreign asset position will depend significantly on our assumptions regarding China's future relative productivity and future relative wealth. Higher relative productivity in China will lead to a more negative net foreign asset position, while higher relative wealth for China will lead to a more positive net foreign asset position. In Section 5 of the paper we will consider how alternative scenarios for relative productivity growth and relative savings rates in China and the rest of the world affect our views on China's likely future net foreign asset position. First, however, we complement the calibration exercise of this section with some non-structural cross-country empirical analysis of net foreign asset positions. 


\section{Non-Structural Empirical Evidence on Determinants of NFA Positions}

In this section of the paper we consider how China's net foreign asset position compares with that of other countries using cross-country regression analysis. ${ }^{4}$ While our approach here is very non-structural, our choice of explanatory variables is for the most part motivated by the theoretical discussion of the previous section. Recall from Equation (14) that net foreign assets as a share of wealth are one minus the ratio of the per capita capital stock to per capita wealth. While this is simply an identity, it is useful for thinking about empirical determinants of the net foreign asset position. In particular, controlling for per capita wealth, variables which make a country a more desirable location for investment will lead to a more negative net foreign asset position. From Equations (11)-(13), per capita capital stocks will be higher in countries with higher productivity and/or less risky returns. Conversely, holding fixed the determinants of investment, the higher is the per capita wealth of a country, the larger will be the net foreign asset position of the country. Of course, this mechanical separation between wealth and capital stocks per capita is an oversimplification. After all, the model of the previous section has shown how the presence of sovereign risk creates a strong home bias in investment patterns. This implies a positive relationship between capital stocks per capita and wealth per capita, and so the overall effect of per capita wealth on the net foreign asset position becomes ambiguous.

We begin by documenting some simple bivariate relationships as a way of data description. In each of these we include a dummy variable for China, as a convenient way of summarizing the extent to which China does, or does not, conform to the crosscountry regularities that we describe. Our sample of countries consists of 62 countries where we have at least 15 annual observations on net foreign assets after $1980 .{ }^{5}$ The data on net foreign assets are taken from Lane and Milesi-Ferretti (2001a). We

\footnotetext{
${ }^{4}$ In part because of only recent data availability, empirical papers on the determinants of net foreign asset positions are scarce. Exceptions are Lane and Milesi-Ferretti (2001a) and Calderon, Loayza, and Serven (2003). Lane (2000) and Lane and Milesi-Ferretti (2003) document determinants of gross foreign asset positions among industrial countries, and Lane and Milesi-Ferretti (2001b) study relate decadal changes in net foreign asset positions in industrial and developing countries to per capita incomes, public debt, and demographic variables.

${ }^{5}$ We drop from this sample Cote d'Ivoire which has a very large negative net foreign asset position and is quite influential for the magnitudes of the slope coefficients in the regressions that follow.
} 
construct wealth by adding net foreign assets to the capital stock, constructed for all countries in the same way as we have described for China in Section 2 of the paper. We then express net foreign assets as a share of wealth, and average over all available annual observations between 1980 and 2000 to construct a single cross-section of 20year averages.

In Table 2 we first show the relationship between the net foreign asset position and per capita wealth relative to world average per capita wealth, where we define the world as the set of countries included in the regression. Not surprisingly, this relationship is strongly positive, indicating that on average capital tends to flow from rich countries to poor countries. This relationship is also quite consistent with the theoretical model of the previous section, where we have seen a positive relationship between per capita wealth and the net foreign asset position. What is also clear is that China is a very strong outlier in this relationship. We have already seen that China is a strong outlier in the relationship between capital stocks per capita and net foreign assets in Figure 5, and empirically per capita capital stocks and per capita wealth are very highly correlated across countries. The China dummy is equal to 0.19 , indicating that on the basis of per capita wealth alone, we would expect China to have a net foreign asset position of -19 percent of wealth.

In the next three columns of Table 2 we introduce three measures intended to capture productivity differences across countries. The first of these is simply the loglevel of total factor productivity obtained from the very simple development accounting exercise that we described in the model calibrations of the previous section. The other two are two measures of institutional quality, which we expect will be important determinants of the attractiveness of a country for both domestic and foreign investment. The first is the ICRG measure of Expropriation Risk that has been widely used as a measure of property rights protection in the literature on institutions and growth. The annual data cover the period 1984-1997, and we average this over all available years for each country. The other is a measure of Rule of Law constructed by Kaufmann, Kraay, and Mastruzzi (2004). As this variable begins only in 1996, we simply use the 1996 value of this variable. The simple correlation between our measure of TFP and the net foreign asset position is negative, while the correlations of the two institutional measures with net foreign asset positions are positive. The latter positive correlations reflect the 
fact that these variables tend to be highly correlated with per capita wealth, which we have not yet controlled for. In these regressions the China residual remains positive and very significant, although substantially smaller than in the first column. We have experimented with a variety of other proxies for productivity differences (using measures capturing policy differences such as trade openness, as well as simply average per capita GDP growth) as well as direct measures of volatility (such as the standard deviation of per capita GDP growth, and the logarithm of one plus the inflation rate). Although we find them plausible, for the most part we find these variables tend to have fairly limited explanatory power in our sample.

The final univariate relationship we document in column (5) of Table 2 is of the net foreign asset position with country size, measured as the logarithm of the country's share in world population. Although there is no role for country size as an independent determinant of net foreign assets in the theory, this relationship is of interest for two reasons. ${ }^{6}$ First, it is very strong and highly significant, and we shall see shortly that it survives the inclusion of other control variables. Second, it is of particular interest in the context of China's size. Given China's large share of world population, it is not surprising that in this regression the China residual falls to close to zero and is no longer significant. In other words, based on size alone, China's zero net foreign asset position is not very surprising. This relationship between net foreign assets and country size has also been documented by Lane and Milesi-Ferretti (2001) and Calderon, Loayza and Serven (2003), using total GDP, and total wealth, respectively.

The multivariate relationships between net foreign assets, wealth, size, and proxies for productivity are more interesting, and are reported in Columns (6), (7) and (8) of Table 2, where we in turn enter our measure of TFP and our two measures of institutional quality. We continue to find a strong positive relationship between net foreign assets and wealth, with a slope that is substantially larger than in the univariate regressions. We now also find that the two institutional quality measures enter with intuitive negative signs: controlling for per capita wealth, better institutional quality makes a country a more desirable location for both domestic and foreign investment,

\footnotetext{
${ }^{6}$ Note in Equations (14)(11)-(13) that the distribution of capital stocks per capita depends only on the distribution of wealth per capita. As a result the net foreign asset position which is one minus the ratio of per capita capital to per capita wealth does not depend on country size.
} 
and so the per capita capital stock is higher and net foreign assets are therefore lower. In contrast, we no longer find a significant direct effect of TFP using our (admittedly very crude) estimate from the development accounting exercise. We also continue to find a very strong positive country size effect on the net foreign asset position. Including measures of per capita wealth, size, and productivity in these three regressions reduces the size of the China dummy to between 5 and 7 percent of wealth. The significance of the China dummy also falls considerably, although it remains significant at the 10 percent level in each case.

Our interpretation of the remaining China dummy is that it captures other policy barriers to capital flows which drive a gap between China's net foreign asset position and what we would expect based on cross-country regularities. In the last column of Table 2, we investigate this interpretation further by including a measure of capital controls, taken from Tamirisa (1999). The measure runs from zero (no controls) to one (highly restrictive controls) and consists of an average of subindices of controls on different types of transactions. We find that this measure of capital controls enters positively and fairly significantly. One interpretation of this is that high values of this index tend to be associated with relatively stricter controls on nonresidents than on residents, resulting in a more positive net foreign asset position. Another interpretation is that capital controls are associated with a less favourable domestic policy environment and this makes foreign assets more attractive than domestic ones. We do also find that the China dummy becomes marginally smaller when we include the capital controls variable, suggesting that at least some part of the China dummy was due to capital controls.

Overall, the results of this section suggest that a very parsimonious set of explanatory variable does a fairly good job of explaining cross-country variation in net foreign assets. However, China departs substantially from this average cross-country relationship, as evidenced by its substantial, and generally significant, residual in the regression. Qualitatively the finding of a positive China dummy in the regressions is consistent with the theoretical calibrations in Section 3, where we saw that a model with only sovereign risk as a disincentive to capital flows predicted a net foreign asset position of -17 percent of wealth for China, which is substantially more negative than China's actual net foreign asset position of about zero. In the regressions we find that the China dummy is positive, but substantially smaller, ranging from 5 to 7 percent of 
wealth in the multivariate specification in Table 2. In the next section of the paper we will explore the quantitative implications of greater international financial integration, as well as of future growth and productivity improvements, for China's net foreign asset position.

\section{Scenarios for China's Current Account and Net Foreign Assets in 2025}

In the previous two sections we have seen that China's net foreign asset position in the future will depend on its per capita wealth and returns relative to the rest of the world. Here we first discuss existing literature on China's high savings rates in order to assess likely future trends in China's saving rates, which will in turn determine its future per capita wealth. We also discuss existing evidence on productivity growth in China in order to assess China's likely future relative productivity levels. In the last part of this section we put these ingredients together with the calibrations and cross-country empirics to come up with predictions for China's future net foreign asset position and the future current accounts required to attain that net foreign asset position.

\section{What will Happen to Saving Rates in China?}

China is well known as a high savings economy. Households save about $25 \%$ of their disposable income, which is high by international standards but not that unusual. Furthermore, this high household savings rate is largely explained by rapid growth of income and the country's demographics ((Modigliani and Cao 2004). The household savings rate is likely to very slowly decline as these underlying factors change, but there will not be much movement because of these factors before 2020 .

Where China is unusual compared to other countries is in the very high enterprise savings rate and government savings rate (Kuijs 2005). In 2003 China's household saving was about $19 \%$ of GDP. This was matched by an equivalent amount of enterprise saving plus about $10 \%$ of GDP in government saving, for a total savings rate of $48 \%$ of GDP. The explanation behind the high enterprise savings rate is a dualistic one in the same way that China's enterprise structure is dualistic. In recent years a dynamic private sector - both foreign and Chinese - has developed alongside a still substantial state sector. The data are best for industrial enterprises, which account for about half of the GDP. According to official sources, in 2003 state enterprises still 
controlled $56 \%$ of the fixed assets of industry, but produced only $33 \%$ of the gross output. The performance of state enterprises has improved over time so that in the aggregate they produce substantial profits. However, both the aggregate statistics and micro evidence show that state enterprises are less productive and profitable than private ones. A large survey of private and state firms in comparable sectors carried out by the World Bank in 2002 and 2003 finds that private firms have TFP about twice the level of state-owned ones in the same sector (Dollar, Hallward-Driemeier, and Mengistae 2005). The median pre-tax rate of return on assets was in the $30 \%$ range, far higher than that of state firms. The aggregate statistics show high profitability of private companies as well (after-tax rate of return on physical assets of 15\% in 2003).

Both private and state firms in China have high rates of reinvestment of retained earnings (enterprise savings). Our interpretation of this is that private firms see a high rate of return and good expansion opportunities. In the case of public firms, however, we hypothesize that the high rate of reinvestment instead reflects poor governance. State steel firms in China, for example, are making a lot of money and reinvesting it in steel. Despite their overall profitability, most state firms have not paid any dividends to the government owners in over a decade. With better governance, it seems likely many SOE investments would not be made.

There is also a very high level of direct government investment from the budget. The government finances 4-5\% of GDP in infrastructure investments from its budget, and also makes a roughly equivalent capital transfer to state enterprises in power, water, and transport. It is harder to measure the returns from this budget-financed investment, but it is certainly plausible that the returns to this are similar to those in the commercial state enterprise sector. Between state enterprises and the budget, the public sector finances something on the order of $20 \%$ of GDP in investment each year. Various pieces of evidence suggest that a substantial amount of this is wasted. So, in looking ahead to plausible scenarios, one possibility is that further economic reform will lead to less waste and a reduction in the very high degree of public sector savings. The kind of reforms that would lead in this direction are commercialization and eventual privatization of enterprises in the infrastructure sectors, further privatization of state enterprises in competitive sectors, development of capital markets that intermediate more efficiently 
between savings and investment, and reform of inter-governmental fiscal relations that support greater public spending on health and education.

Kuijs and Wang (2005) calibrate a more capital-efficient growth scenario for China in which the economy grows at about the same rate as in recent years, but there is substantially less public savings (with the overall savings rate about one-fifth lower). So, in thinking about different savings scenarios, we consider one in which the status quo continues, and interpret this as a "stalled reform" scenario in which there continues to be a lot of inefficiency in the public sector and poor intermediation between savings and investment. In our "high reform" scenario we consider a decline in the aggregate savings rate of one-fifth.

\section{What Will Happen to Productivity in China?}

Estimates of TFP growth in China are abundant, vary considerably. ${ }^{7}$ In a recent very careful study Young (2003) concludes that various -- although not equally valid -interpretations of Chinese data would result in TFP growth rates ranging from 0 to 6 percent per year! However, Young's preferred estimate is a very reasonable 1.4 percent per year, for the non-agricultural economy during the period 1978-1998. This estimate is in the same vicinity as Kraay (1996), who estimates a TFP growth rate of 1.8 percent per year for the period 1978-1994. These two estimates tend to be at the low end of those in the literature. For example, Borensztein and Ostry (1996) and $\mathrm{Hu}$ and Khan (1997) provide estimates of TFP growth of 3.8 and 3.9 percent per year over the period 19781994. In this subsection we make two points. The first is that relatively modest TFP growth rates for China are most likely higher than average productivity growth in the rest of the world, implying that China's level of productivity relative to the rest of the world has been rising over time. The second is that there is substantial scope for further productivity growth in China due to the continued reallocation of factors of production from low-productivity uses (agriculture, and the state sector) to high-productivity uses (non-agriculture, and the private sector). While this intersectoral factor reallocation is not pure TFP growth, it will contribute to higher productivity levels in China relative to the rest of the world.

\footnotetext{
${ }^{7}$ In addition to those cited in the text, see for example Li (1992), Chow (1993), Woo (1995), Borenzstein and Ostry (1996), and Hu and Khan (1996).
} 
We are not aware of any study that provides serious estimates of TFP growth for the world as a whole, that we could use to construct estimates of China's past productivity growth performance relative to the rest of the world. All we have is the very crude development accounting exercise that we did in Section 3 of the paper. If we take this at face value, we find that productivity growth in China (measured as the residual from a simple Cobb-Douglas production function) grew at 0.7 percent per year between 1980 and 2000, while productivity growth in an aggregate of the rest of the world was zero. These are of course very naive estimates of productivity growth, but they do support the basic premise that productivity growth in China has been faster than in the rest of the world. Moreover, the estimates for China are in fact quite low, mostly reflecting the fact that we are using growth rates of per capita GDP from the Penn World Tables which makes fairly substantial -- and somewhat arbitrary -- downward adjustments to China's growth rate.

It is also informative to look at how China's productivity growth rates compare with industrial countries where we have careful estimates of TFP growth. For the United States, for example, Jorgenson and Stiroh (2000) estimate a TFP growth rate of 0.6 percent per year between 1959 and 1998, albeit with a modest acceleration to around 1 percent per year during the second half of the 1990s. Somewhat higher estimates of US TFP growth during the 1990s are provided by Basu, Fernald, and Shapiro (2001) who argue for a productivity growth rate of 2 percent per year during the 1990s (adjustment costs mean Solow residual understates TFP growth). For the UK, Basu, Fernald, and Oulton (2003) find TFP growth rates around 1 percent per year between 1980 and 2000. This suggests that reasonable estimates of TFP growth rates in China in the 1.5 to 2 percent per year range may well be somewhat higher than those in industrial countries.

Our second main point is that productivity growth in China is likely to be significantly higher than pure TFP growth because of sectoral reallocation of factors or production. For example, Kraay (1996) estimates that TFP growth for China was 1.8 percent per year over the period 1978-1994, but that overall productivity grew by 3.2 percent per year, with the difference of 1.5 percent per year capturing intersectoral factor reallocation. Here we present a simplified accounting framework that can be used to measure these efficiency gains from reallocation, and use it to speculate as to the scope 
for further efficiency gains from this type of reallocation will be over the next 20 years. ${ }^{8}$ Suppose that value added in sector $\mathrm{i}$ of the economy is produced with the following production function: $Y_{i}=F_{i}\left(K_{i}, L_{i}, A_{i}\right)$ where $K$ and $L$ are capital and labour inputs, and $A$ is shift factor in the production function. Total Let $\mathrm{gX}$ denote the growth rate of variable $X$. The growth rate of total value added, i.e. the sum of value added across sectors, is simply the share-weighted growth rate of the individual sectors:

$$
g Y=\sum_{i} \frac{Y_{i}}{Y} \cdot g Y_{i}
$$

The growth rate of value added in each sector is a weighted average of the growth rates of capital and labour in that sector, plus a residual which is conventionally interpreted as total factor productivity growth. Inserting this into the aggregate growth rate gives:

$$
g Y=\sum_{i} \frac{Y_{i}}{Y} \cdot\left(\frac{K_{i}}{Y_{i}} \cdot M P K_{i} \cdot g K_{i}+\frac{L_{i}}{Y_{i}} \cdot M P L_{i} \cdot g L_{i}+d P_{i}\right)
$$

where $\mathrm{MPK}_{\mathrm{i}}$ and $\mathrm{MPL}_{\mathrm{i}}$ denote the marginal products of capital and labour in sector $\mathrm{i}$, and $\mathrm{dP}_{\mathrm{i}}$ denotes productivity growth in sector $\mathrm{i}$. Let $\alpha_{\mathrm{K}}=\sum_{\mathrm{i}} \frac{\mathrm{Y}_{\mathrm{i}}}{\mathrm{Y}} \cdot \frac{\mathrm{K}_{\mathrm{i}}}{\mathrm{Y}_{\mathrm{i}}} \cdot \mathrm{MPK}_{\mathrm{i}}$ and $\alpha_{L}=\sum_{i} \frac{Y_{i}}{Y} \cdot \frac{L_{i}}{Y_{i}} \cdot M P L_{i}$ denote the elasticities of aggregate output with respect to total capital and labour input, $\mathrm{K}$ and L, which are simply the sums of the sectoral capital and labour inputs. Aggregate total factor productivity growth is conventionally obtained by subtracting the growth rates of aggregate capital and labour from total output growth, weighted by these output elasticities, i.e. $g P=g Y-\alpha_{K} \cdot g K-\alpha_{L} \cdot g L$. Inserting this into Equation (16) gives, after some manipulation, the following expression for aggregate total factor productivity growth:

\footnotetext{
${ }^{8}$ For a more complete decomposition, with application to the US, see Basu and Fernald (1995).
} 


$$
\begin{aligned}
g P= & \sum_{i} \frac{K_{i}}{Y} \cdot\left(M P K_{i}-M P K\right) \cdot\left(g K_{i}-g K\right)+ \\
& \sum_{i} \frac{L_{i}}{Y} \cdot\left(M P L_{i}-M P L\right) \cdot\left(g L_{i}-g L\right)+ \\
& \sum_{i} \frac{Y_{i}}{Y} \cdot d P_{i}
\end{aligned}
$$

where MPK and MPL are the aggregate marginal products of capital and labour, i.e. the derivatives of total production with respect to $K$ and $L$. The third term in Equation (17) is the contribution of within-sector TFP growth to aggregate TFP growth. The first two terms are the contributions of reallocations of factors across sectors to aggregate TFP growth. These expressions are very intuitive. If the growth rate of capital (labour) input is higher than average in a sector where the marginal product of capital (labour) is higher than average, this will contribute positively to higher aggregate productivity growth.

We first use this framework to provide estimates of the contribution of intersectoral factor reallocation to growth in China between 1984 and 1999, following the calculations in Kraay (1996) and World Bank (1996). We separate the Chinese economy into agriculture, industry, and services, and within industry and services distinguish between state-owned firms, collectively-owned firms, and other ownership firms consisting primarily of foreign investment, and private firms. Using published Chinese data and a number of assumptions detailed in Appendix 1 of World Bank (1996) we are able to construct estimates of the distribution of real value added and the distribution of employment across these seven sectors. Assuming a Cobb Douglas production function and using output elasticities of capital and labour as described in World Bank (1996), we are able to calculate the second line of Equation (17) which captures the contribution of labour reallocation to aggregate productivity growth. The results of these updated calculations through 1999 are reported in Table $3 .{ }^{9}$ Factor reallocation has contributed about 1.3 percentage points of growth between 1984 and 1999 , and the pace of this factor reallocation has remained fairly stable. What has

\footnotetext{
${ }^{9}$ Unfortunately we are not able to update these calculations past 1999 due to a break in the series on the distribution of industrial production by ownership. Up to 1999, the China Statistical Yearbooks report this distribution for all firms, but after 1999 they report this information only for large firms above a certain size threshold, and these large firms are disproportionately stateowned.
} 
changed is the composition: in earlier periods labour reallocation out of agriculture was more important, while in more recent periods labour reallocation out of the state sector was more important.

Will factor reallocation continue to contribute to productivity growth in China over the next 20 years? The answer to this depends on the extent to which intersectoral differences in marginal products of factors remain, and the scope for future reallocation of factors to those sectors where marginal products are relatively high. In Figure 7 we present some very rudimentary evidence on this using more recent data for China. In the top panel we report the ratio of value added per worker in the private sector relative overall industry in China. The relative labour productivity advantage of the private sector in China has fallen somewhat over time, but remains quite high with the private sector having labour productivity around 2.5 times that of the industry as a whole. This is a comparison of average, rather than marginal products, and it is the latter that matter for intersectoral reallocation. However, if we assume a Cobb-Douglas production function for value added, the only difference between marginal products and average products is the output elasticity of labour. It seems clear from Figure 7 that the output elasticity of labour would have to be vastly smaller in the private sector than in industry as a whole for these labour productivity differences not to translate into sizeable differences in marginal products. We also note that although the share of the private sector in total employment has grown very rapidly, it still is quite modest at only 20 percent of industrial employment.

In the bottom panel of Figure 7 we report some evidence on the scope for reallocation of capital across ownership forms. We draw on data for large and mediumsized industrial enterprises reported in recent issues of the China Statistical Yearbook. This source provides information on value added and fixed assets, disaggregated by forms of ownership. Consistent with the top panel of this figure, we identify the private sector as all non-state and non-collective firms, and we again report the ratio of the average product of capital in the private sector relative to the total. Over the past several years the average product of capital in the private sector has been 50 percent higher than average, which is suggestive of non-trivial differences in marginal products across ownership forms. And as with labour, although the share of the private sector has increased sharply, it is still quite modest at about 30 percent. 
Taken together, the evidence reported in Figure 7 suggests that there is considerable scope for future productivity gains from further factor reallocation across ownership forms, given the productivity advantages of the private sector and the relatively small share of labour and capital currently allocated to it. Adding this to reasonable estimates of pure productivity growth in the 1 to 2 percent range, suggests to us that scenarios in which China's productivity level gains on the world average over the next 20 years are reasonable ones to consider.

\section{Scenarios for China's Current Account and NFA Position}

We now put all the pieces of the analysis together to come up with estimates of China's net foreign asset position in 2025, and of the pattern of current account surpluses or deficits required to reach this position over the next 20 years. We consider three scenarios. Scenario 1 is basically a continuation of recent trends. China's savings rate has reached 25 percent of PPP GDP; the economy has been growing at 6 percent per capita according to the Penn World Tables; and the rest of the world's productivity advantage over China declined from a ratio of 1.2 at the beginning of reform to about 1.0 today. So, one possible scenario is a continuation of these trends (Scenario 1). We think a more likely scenario is that there is some slowing of China's growth rate, for example to 5 percent per annum. If reform continues, there will be ongoing productivity improvements as resources shift out of agriculture to services and industry, and out of the state sector toward the private. So, in Scenario 2 we have somewhat slower aggregate growth as result of diminishing returns, but a continuation of the historical trend in aggregate TFP and a reduction in the savings rate to about $20 \%$ of PPP GDP. As discussed above, some of the current high savings reflects distortions and institutional weaknesses, so that continued reform would result in lower overall savings. In our final Scenario 3, we consider a stagnation in reform: savings rate remains very high at $25 \%$ of PPP GDP, whereas productivity growth stagnates relative to the rest of the world and the overall growth rate declines to 4 percent per capita because of diminishing returns. If China's reform trend continues, then we think that Scenario 2 would be the most likely outcome. 
We turn these assumptions into predictions for China's net foreign asset position as follows. Our assumption on average per capita GDP growth allows us to project forward per capita GDP. Our assumption on future saving rates then gives us the gross change in wealth for each future year. We then estimate per capita wealth by cumulating these gross changes in wealth and subtracting 6 percent depreciation per year. This gives us per capita wealth in 2025 which, as we have seen in Sections 3 and 4 of the paper, is a key determinant of China's future net foreign asset position. In the calibration exercise the relevant variable is China's per capita wealth relative to that of the rest of the world. We assume that the growth rate of per capita wealth of the rest of the world is equal to its historical rate over the period 1980-2000. This gives us China's relative per capita wealth in 2025 . In our first and third scenarios, which feature continued very high saving rates, we set the saving rate at 25 percent of GDP, which is roughly equal to the current saving rate in PPP terms. This is of course much lower than the rate in local currency terms, reflecting the relatively high cost of investment goods in China. We use the lower PPP saving rates since our estimates of wealth are measured in international prices. In the second scenario with lower saving we reduce the saving rate to its historical average between 1980 and 2005 of 20 percent. Our assumptions for per capita GDP growth for the three scenarios are 6, 5, and 4 percent respectively, where $6 \%$ is the historical growth rate of GDP per capita between 1980 and 2005 as reported in the Penn World Tables. ${ }^{10}$

We are more eclectic in our approach to future productivity levels, which is the other key determinant of the net foreign asset position. For the calibration model, the relevant variable is $\pi$ which measures ROW's productivity advantage. In our first two scenarios we assume that relative productivity growth is equal to its historical average growth rate. Measured relative TFP from our crude development accounting exercise was 1.2 in 1980, and 1 in 2000. Extrapolating this annual average growth rate in relative productivity of 0.8 percent per year into the future gives us a value of $\pi=0.87$ in 2025 . We note that this is a fairly conservative estimate of TFP growth for China. In our development accounting exercise average TFP growth for ROW between 1980 and

\footnotetext{
${ }^{10}$ The PWT includes a more or less arbitrary, but not unreasonable, downward adjustment in its estimates of China's GDP growth, reflecting a variety of concerns about the quality of Chinese national accounts data. See Young (2003) for a very thorough discussion of the issues. The PWT reports data only through 2000 for China, we extrapolate to 2005 using (unadjusted) constant local currency growth rates.
} 
2000 was roughly zero, so this implies an absolute productivity growth rate for China of only 0.8 percent per year. This is more conservative than the estimates of Young (2003) who takes one of the most skeptical views in the literature of China's productivity growth. In the third scenario with stagnant productivity growth we assume that $\pi=1$ in 2025 . We then insert these estimates of future relative wealth and relative productivity into the model to obtain predicted net foreign asset positions.

In the cross-country empirical exercise we found that this one admittedly very crude estimate of productivity did not enter significantly in our net foreign asset regressions. For the first two scenarios, we interpret continued TFP growth as continued improvements in institutional quality which we did find to be a significant determinant of net foreign asset positions. In particular, between the 1980s and the 1990s, China's rating on the ICRG Expropriation Risk measure improved by about one point on a 10point scale, so we assume a further improvement of one point over the next 20 years. In the third scenario we assume no change in the institutional quality variable. Finally, for all three scenarios we assume that barriers to capital flows into and out of China disappear over the next 20 years. We implement this assumption by having the China residual in the regression go to zero, as well as by assuming that the measure of capital controls falls from China's level of 0.9 to 0.2 , which is typically of industrial countries on this measure of capital controls. We then obtain our predicted net foreign asset position for 2025 by multiplying the assumed changes in right-hand-side variables by the corresponding estimated coefficients, and subtracting the China dummy. For this exercise we use the specification in Column (9) of Table 2.

We summarize our results in Table 4. The columns of the table correspond to the three scenarios described above. In the first three rows we report our assumptions on future growth and saving rates, and in the third row we report the implication of these assumptions for per capita wealth in 2025 . Wealth rises to $\$ 35,000$ per capita in 1996 PPP-adjusted terms in the first scenario, a 3.5-fold increase over current levels of about $\$ 10,000$ per capita. While this is a dramatic increase, in proportional terms it is much smaller than the increase observed between 1980 and 2005, admittedly from a very low base. Slower growth and/or lower saving rates in the second and third scenarios lead to substantially smaller increases in per capita wealth, to $\$ 25,000$ and $\$ 27,000$ respectively. 
The next panel of Table 4 reports our predictions for the net foreign asset position based on the calibrated model of Section 3. In the first two scenarios we obtain net foreign asset positions of -5 percent and -9 percent of wealth, respectively. Increases in China's relative wealth lead to more positive net foreign assets, while increases in China's relative productivity lead to more negative net foreign assets. In the calibrations the increases in wealth dominate, so that the predicted net foreign asset positions of -5 and -9 percent of wealth are substantially more positive than the calibrations for the present of -17 percent of wealth that we saw in Section 3. In the third scenario the predicted net foreign asset position is much less negative at -3 percent of wealth, thanks to our assumption of no relative productivity growth. We finally generate predictions for the average current account deficit consistent with this future net foreign asset position. We make no attempt to seriously model the process of adjustment to this new net foreign asset position. Rather we simply assume that the foreign asset share changes linearly over time from its current value of nearly zero to its predicted value. Then for each period we can compute the change in net foreign assets (i.e. the current account, since we have no valuation adjustments), and express it as a share of GDP at market prices. We use this denominator at market exchange rates so that the resulting figures are a bit more familiar. We find that China would have to run substantial, but not unreasonable, current account deficits ranging from -2 percent of GDP in the third scenario, to -5 percent of GDP in the second scenario, in order to attain our predicted net foreign asset positions. Our results based on the non-structural empirical exercise are reported in the bottom panel of Table 4, and are not very different from those based on the calibration exercise. We obtain predicted net foreign asset positions of $-3,-6$, and -1 percent of wealth in the three scenarios, and the associated current account deficits are somewhat smaller than in the middle panel of the table.

While at first glance these current account deficits may seem large given our quite modest predictions for China's future net foreign asset position, it is important to remember that this predicted foreign asset share is applied to per capita wealth measured in international prices. This per capita wealth is very large relative to GDP at market prices, reflecting first China's low PPP exchange rate of about 0.25 in the Penn World Tables, and in addition the fact that projected wealth is between 1.5 and 2 times GDP at PPP. Thus a net foreign asset position of -5 percent of wealth in PPP terms 
would correspond to nearly -40 percent of GDP at market exchange rates, reaching this net foreign asset position would require fairly substantial current account deficits relative to GDP at market exchange rates. In addition, in our three scenarios the wealth to GDP ratio rises thanks to high saving rates, and this too implies larger current account deficits as the target amount of net foreign assets increases relative to wealth if the net foreign asset share were fixed.

\section{Conclusions}

China is a developing country with a low capital-labor ratio, reasonably good economic institutions, and high returns to private investment. In the one area of the capital account that is reasonably open - inward flows of direct foreign investment - we observe inflows that are large relative to global capital flows and to the size of the Chinese economy. The foreign private investors in China are earning a good return and reinvesting it. Other areas of the capital account are quite closed, however, and in recent years net inflows of direct investment have been more than offset by reserve accumulation. So, China stands out among lower-middle-income countries, with a slightly positive net foreign asset position.

A model of cross-border capital flows suggests that in an open capital account environment China should be a significant net debtor with net foreign assets of -17 percent of wealth. The intuition of this is straightforward: China owns a small share of global wealth but has a high-return environment, so that market forces work toward significant net inflows of capital. Non-structural cross-country empirical analysis also finds China anomalous among developing countries with 8-13 percentage points more of wealth in NFA than is predicted by its characteristics. In general, low-middle-income developing countries with good institutions are net debtors, but China is a modest net creditor.

We then examine various scenarios for the future. It seems likely that China's financial integration with the global economy will increase, so that actual net foreign asset positions in the future will be closer to predicted ones. We calibrate and estimate a number of different scenarios. In our view the most plausible scenario is one in which China's reform continues, so that per capita GDP growth and productivity growth are 
relatively high, while savings declines in response to financial sector improvements. In this scenario China is predicted to have net foreign assets of -9 percent of wealth in 20 years. To achieve this position would require average current account deficits of 5 percent of GDP between now and then, a large adjustment from the current 6 percent of GDP surplus. Even with stagnant reform and continued very high savings, we predict China to be a modest net debtor in 2025, requiring current account deficits of 2 percent of GDP to get there.

While there is a lot of uncertainty around these scenarios, they emphasize a fundamental point: as China continues its reform and liberalizes its financial system, including the capital account, a significant amount of the world's wealth is going to want to move into this attractive location. That capital inflow can help increase output and welfare in China, but managing the adjustment will be no small feat. And the more successful China's reform, the greater the required adjustment is likely to be. 


\section{References}

Basu, Susanto, John Fernald, Nicholas Oulton, and Sylaja Srinivasan (2003). "The Case of Missing Productivity Growth: Or, Does Information Technology Explain Why Productivity Accelerated in the United States but Not in the United Kingdom?". NBER Macroeconomics Annual.

Borensztein, Eduardo and Jonathan D. Ostry (1996). "Accounting for China's Growth Performance". American Economic Review. Vol. 80, No. 2, pp. 224-228.

Calderon, Cesar, Norman Loayza, and Luis Serven (2003). "Do Capital Flows Respond to Risk and Return?". Manuscript, The World Bank.

Chow, Gregory (1993). "Capital Formation and Economic Growth in China". Quarterly Journal of Economics pp. 809-842.

Dollar, David, Mary Hallward-Driemeier, and Taye Mengistae (2005). "Investment Climate and Firm Performance in Developing Economies," Economic Development and Cultural Change 54(1): 1-31.

Hu, F. Zuliu and Mohsin S. Khan (1997). "Why Is China Growing So Fast?". International Monetary Fund Staff Papers. 44(1):103-31.

Jefferson, Gary, Albert G.Z. Hu, Xiaojing Guan, and Xiaoyun Yu (2003). "Ownership, Performance, and innovation in China's large- and medium-size industrial enterprise sector," China Economic Review 14: 89-113.

Jorgenson, Dale and Kevin Stiroh (2000). "Raising the Speed Limit: US Economic Growth in the Information Age". Brookings Papers on Economic Activity. 1:125:211.

Kuijs, Louis (2005). "Investment and Saving in China," World Bank Policy Research Working Paper No. 3633.

Kuijs, Louis, and Tao Wang (2005). "China's Pattern of Growth: Moving to Sustainability and Reducing Inequality?" World Bank China Office Research Working Paper No. 2.

Kraay, Aart, Norman Loayza, Luis Serven, and Jaume Ventura (2005). "Country Portfolios". Journal of the European Economic Association. 3(4):914-945.

Lane, Philip and Gian Maria Milesi-Ferretti (2001a). "The External Wealth of Nations: Measures of Foreign Assets and Liabilities for Industrial and Developing Countries". ournal of International Economics". 55:263-294.

Lane, Philip and Gian Maria Milesi-Ferretti (2001b). "Long-Term Capital Movements", in Ben Bernanke and Kenneth Rogoff, (eds). NBER Macroeconomics Annual.

Lane, Philip and Gian Maria Milesi-Ferretti (2001b). "International Financial Integration". International Monetary Fund Staff Papers. 50:82-113.

Lane, Philip (2000). "International Investment Positions: A Cross-Sectional Analysis". Journal of International Money and Finance. 19:513-534. 
Li, Jingwen (1992). "Productivity and China's Economic Growth". Economic Studies Quarterly. Vol. 43, No. 5, pp. 337-350.

Modigliani, Franco, and Shi Larry Cao (2004). "The Chinese Saving Puzzle and the LifeCycle Hypothesis," Journal of Economic Literature.

Prasad, Eswar, and Shang-Jin Wei (2005). "The Chinese Approach to Capital Inflows: Patterns and Possible Explanations," IMF Working Paper WP/05/79.

Wang, Yan, and Yudong Yao (2003). Sources of China's economic growth 1952-1999: incorporating human capital accumulation," China Economic Review 14: 32-52.

Woo, Wing Thye (1995). "Chinese Economic Growth: Sources and Prospects". Manuscript, University of California at Davis.

World Bank (1996). "The Chinese Economy: Fighting Inflation, Deepening Reforms". Country Economic Memorandum, China-Mongolia Department.

Young, Alwyn (2003). "Gold Into Base Metals: Productivity Growth in the People's Republic of China During the Reform Period". Journal of Political Economy. 111(6):1220-1261. 
Table 1: Geographical Origin of FDI Inflows into China

\begin{tabular}{|c|c|c|c|c|c|}
\hline & 2000 & 2001 & 2002 & 2003 & $\begin{array}{l}\text { Corporate tax rate of } \\
\text { scurce country }\end{array}$ \\
\hline & \multicolumn{4}{|c|}{ USD billion } & Per cent \\
\hline Hong Kong, Chira & 15.5 & 16.7 & 17.9 & 17.7 & 17.5 \\
\hline Brittsh Virgin Islands & 3.8 & 5.0 & 6.1 & 5.8 & 1.0 \\
\hline Japan & 2.9 & 43 & 4.2 & 5.1 & 42.0 \\
\hline Korea & 1.5 & 2.2 & 2.7 & 4.5 & 29.7 \\
\hline United States & 4.4 & 4.4 & 5.4 & 4.2 & 40.0 \\
\hline Chinese Talpel & 2.3 & 3.0 & 4.0 & 3.4 & 25.0 \\
\hline Singapore & 2.2 & 2.1 & 2.3 & 2.1 & 22.0 \\
\hline Western Samoa & 03 & 0.5 & 0.9 & 1.0 & 0.0 \\
\hline Cayman Istands & 0.6 & 1.1 & 1.2 & 0.9 & 0.0 \\
\hline Germany & 1.0 & 1.2 & 0.9 & 0.9 & 19.0 \\
\hline Total of above & 34.5 & 40.6 & 45.6 & 45.4 & 21.0 \\
\hline Total & 40.7 & 46.9 & 52.7 & 53.5 & \\
\hline Per cent of GDP & 3.8 & 4.0 & 4.2 & 3.8 & \\
\hline
\end{tabular}

Note: Countries are grouped in order 2003 inflows.

Source: CEIC database, KPMG (2004) and national governments. 
Table 2: Cross-Country Regressions of NFA Position

(Dependent Variable is Net Foreign Assets/Wealth, Average 1980-2000)

\begin{tabular}{|c|c|c|c|c|c|c|c|c|c|}
\hline & (1) & (2) & (3) & (4) & (5) & (6) & (7) & (8) & (9) \\
\hline $\begin{array}{l}\text { In(Wealth } \\
\text { per Capita) }\end{array}$ & $\begin{array}{l}0.049 \\
(0.012)^{\star \star \star}\end{array}$ & & & & & $\begin{array}{l}0.053 \\
(0.012)^{\star \star *}\end{array}$ & $\begin{array}{l}0.081 \\
(0.017)^{\star \star \star}\end{array}$ & $\begin{array}{l}0.088 \\
(0.023)^{\star \star \star}\end{array}$ & $\begin{array}{l}0.102 \\
(0.022)^{\star \star \star}\end{array}$ \\
\hline $\ln (T F P)$ & & $\begin{array}{l}-0.149 \\
(0.083)^{\star}\end{array}$ & & & & $\begin{array}{l}0.008 \\
(0.083)\end{array}$ & & & \\
\hline Rule of Law & & & $\begin{array}{l}0.034 \\
(0.015)^{\star \star}\end{array}$ & & & & $\begin{array}{l}-0.041 \\
(0.021)^{*}\end{array}$ & & \\
\hline $\begin{array}{l}\text { Expropriation } \\
\text { Risk }\end{array}$ & & & & $\begin{array}{l}0.033 \\
(0.010)^{\star \star \star}\end{array}$ & & & & $\begin{array}{l}-0.034 \\
(0.017)^{\star}\end{array}$ & $\begin{array}{l}-0.038 \\
(0.017)^{\star \star}\end{array}$ \\
\hline $\begin{array}{l}\text { In(Population } \\
\text { Share) }\end{array}$ & & & & & $\begin{array}{l}0.032 \\
(0.008)^{\star \star \star}\end{array}$ & $\begin{array}{l}0.035 \\
(0.008)^{\star \star \star}\end{array}$ & $\begin{array}{l}0.033 \\
(0.008)^{\star \star \star}\end{array}$ & $\begin{array}{l}0.041 \\
(0.009)^{\star \star \star}\end{array}$ & $\begin{array}{l}0.037 \\
(0.009)^{\star \star \star}\end{array}$ \\
\hline $\begin{array}{l}\text { Capital } \\
\text { Controls }\end{array}$ & & & & & & & & & $\begin{array}{l}0.081 \\
(0.042)^{\star}\end{array}$ \\
\hline $\begin{array}{l}\text { China } \\
\text { Dummy }\end{array}$ & $\begin{array}{l}0.191 \\
(0.024)^{\star \star \star}\end{array}$ & $\begin{array}{l}0.097 \\
(0.020)^{\star \star \star}\end{array}$ & $\begin{array}{l}0.154 \\
(0.022)^{\star \star \star}\end{array}$ & $\begin{array}{l}0.117 \\
(0.014)^{\star \star \star}\end{array}$ & $\begin{array}{l}-0.021 \\
(0.033)\end{array}$ & $\begin{array}{l}0.047 \\
(0.027)^{\star}\end{array}$ & $\begin{array}{l}0.052 \\
(0.030)^{\star}\end{array}$ & $\begin{array}{l}0.071 \\
(0.037)^{\star}\end{array}$ & $\begin{array}{l}0.067 \\
(0.036)^{\star}\end{array}$ \\
\hline Constant & $\begin{array}{l}-0.112 \\
(0.013)^{\star \star \star}\end{array}$ & $\begin{array}{l}0.149 \\
(0.151)\end{array}$ & $\begin{array}{l}-0.138 \\
(0.018)^{\star \star \star}\end{array}$ & $\begin{array}{l}-0.384 \\
(0.080)^{\star \star \star}\end{array}$ & $\begin{array}{l}0.061 \\
(0.043)\end{array}$ & $\begin{array}{l}0.069 \\
(0.131)\end{array}$ & $\begin{array}{l}0.101 \\
(0.044)^{\star *}\end{array}$ & $\begin{array}{l}0.394 \\
(0.170)^{\star \star}\end{array}$ & $\begin{array}{l}0.379 \\
(0.162)^{\star *}\end{array}$ \\
\hline $\begin{array}{l}\text { Observations } \\
\text { R-squared }\end{array}$ & $\begin{array}{l}61 \\
0.25\end{array}$ & $\begin{array}{l}61 \\
0.07\end{array}$ & $\begin{array}{l}61 \\
0.10\end{array}$ & $\begin{array}{l}60 \\
0.17\end{array}$ & $\begin{array}{l}61 \\
0.19\end{array}$ & $\begin{array}{l}61 \\
0.46\end{array}$ & $\begin{array}{l}61 \\
0.49\end{array}$ & $\begin{array}{l}60 \\
0.51\end{array}$ & $\begin{array}{l}60 \\
0.54\end{array}$ \\
\hline
\end{tabular}

Robust standard errors in parentheses

* significant at 10\%; ** significant at 5\%; *** significant at $1 \%$ 
Table 3: Sectoral Reallocation and Growth in China (Contribution to Growth, Percent Per Year)

\begin{tabular}{l|ccc}
\hline & Overall & $\begin{array}{c}\text { Reallocation of } \\
\text { Labour Out of } \\
\text { Agriculture }\end{array}$ & $\begin{array}{c}\text { Reallocation of } \\
\text { Labour Across } \\
\text { Ownership Forms }\end{array}$ \\
$1985-89$ & 1.39 & 1.31 & 0.07 \\
$1990-94$ & 1.36 & 0.46 & 0.90 \\
$1985-99$ & 1.29 & 0.16 & 1.13 \\
& 1.34 & 0.64 & 0.70 \\
\hline
\end{tabular}


Table 4: Scenarios for Current Account and Net Foreign Assets

\begin{tabular}{|c|c|c|c|}
\hline & Scenario 1 & Scenario 2 & Scenario 3 \\
\hline Per Capita GDP Growth & $6 \%$ & $5 \%$ & $4 \%$ \\
\hline Saving Rates & $25 \%$ & $20 \%$ & $25 \%$ \\
\hline Productivity & $\begin{array}{l}\text { Past Trends } \\
\text { Continue }\end{array}$ & $\begin{array}{l}\text { Past Trends } \\
\text { Continue }\end{array}$ & $\begin{array}{l}\text { Productivity } \\
\text { Stagnates }\end{array}$ \\
\hline Per Capita Wealth 2025 & 35000 & 25000 & 27000 \\
\hline \multicolumn{4}{|c|}{ Model Calibrations } \\
\hline $\begin{array}{l}\text { ROW relative } \\
\text { productivity } \pi\end{array}$ & 0.87 & 0.87 & 1.0 \\
\hline $\begin{array}{l}\text { Per Capita Wealth } \\
\text { Relative to ROW }\end{array}$ & 1.1 & 0.8 & 0.9 \\
\hline $\begin{array}{l}\text { Predicted NFA/Wealth } \\
\text { in } 2025\end{array}$ & $-5 \%$ & $-9 \%$ & $-3 \%$ \\
\hline Average Current & $-3 \%$ & $-5 \%$ & $-2 \%$ \\
\hline \multicolumn{4}{|c|}{ Non-Structural Cross-Country Empirics } \\
\hline $\begin{array}{l}\text { Change in } \\
\text { Expropriation Risk } \\
\text { Measure }\end{array}$ & 1 & 1 & 0 \\
\hline $\begin{array}{l}\text { Change in log(Per } \\
\text { Capita Wealth Relative } \\
\text { to US) } 2005-2025\end{array}$ & 1.3 & 1 & 1.1 \\
\hline $\begin{array}{l}\text { Predicted NFA/Wealth } \\
\text { in } 2025\end{array}$ & $-3 \%$ & $-6 \%$ & $-1 \%$ \\
\hline $\begin{array}{l}\text { Average Current } \\
\text { Account Deficit/GDP at } \\
\text { Market Prices, 2005- } \\
2025\end{array}$ & $-2 \%$ & $-4 \%$ & $-1 \%$ \\
\hline
\end{tabular}


Figure 1: Saving and Investment in China

(Fraction of GDP at Market Prices)

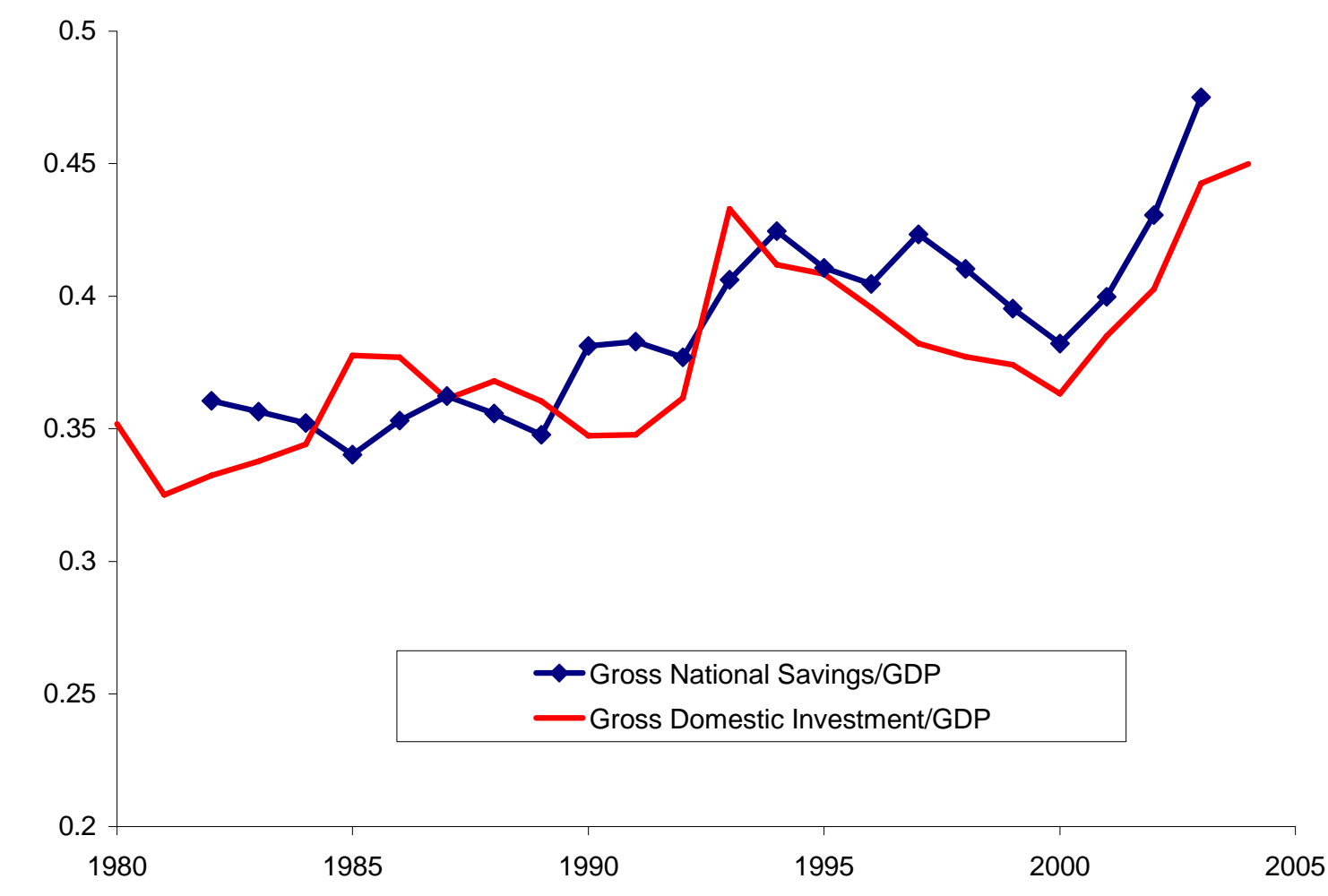




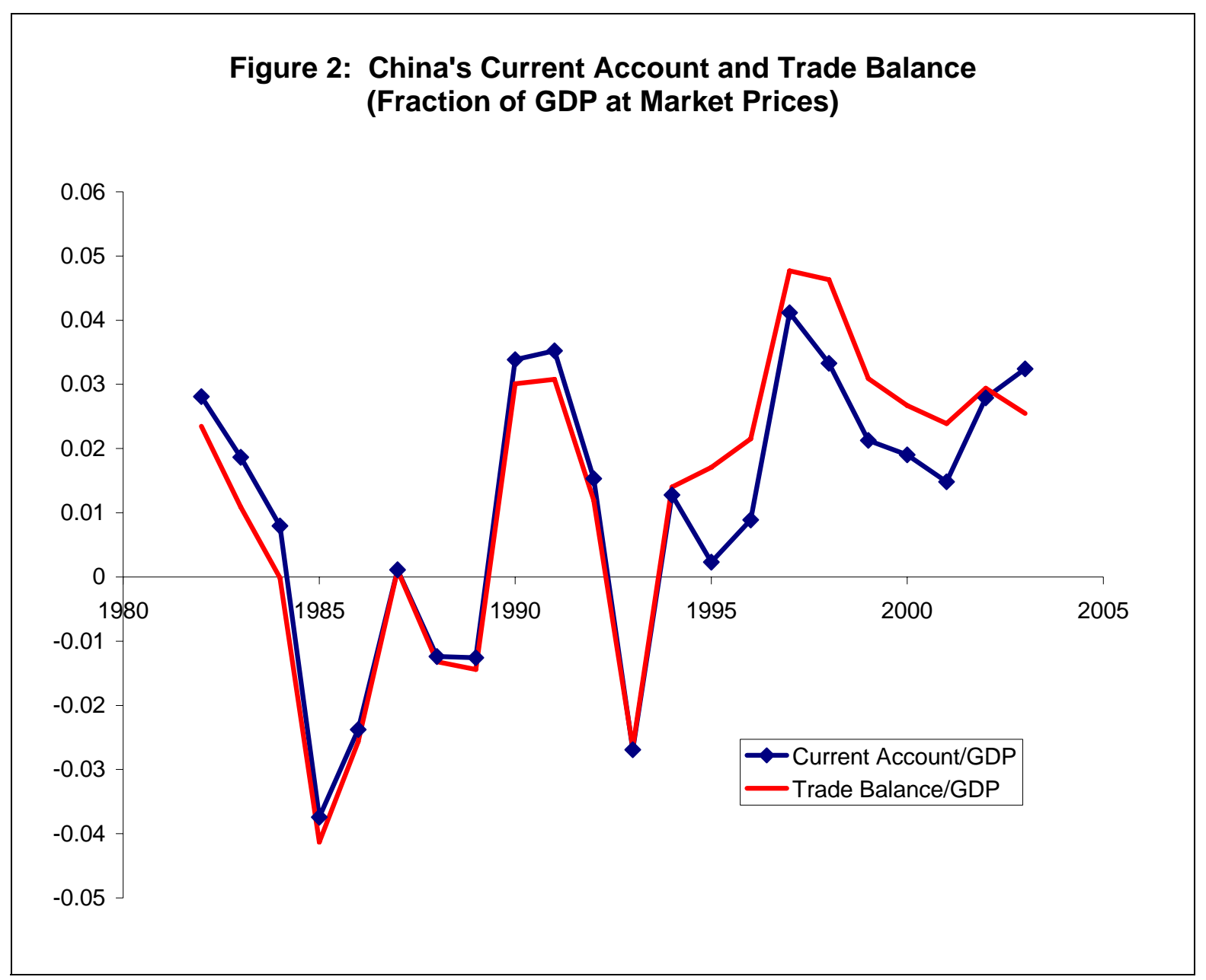


Figure 3: China's Net Foreign Asset Position

(Fraction of GDP at Market Prices and of Wealth at International Prices)

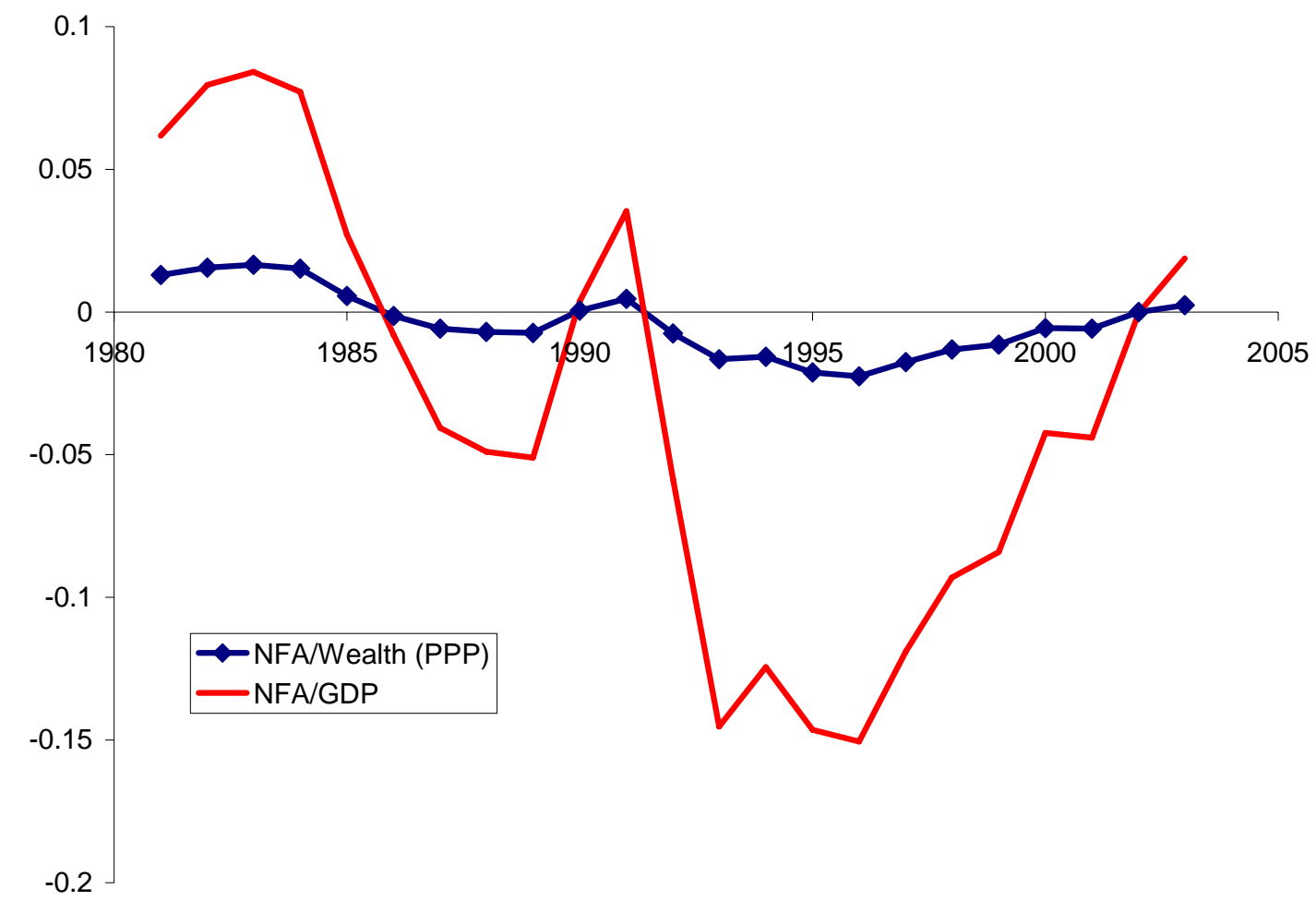




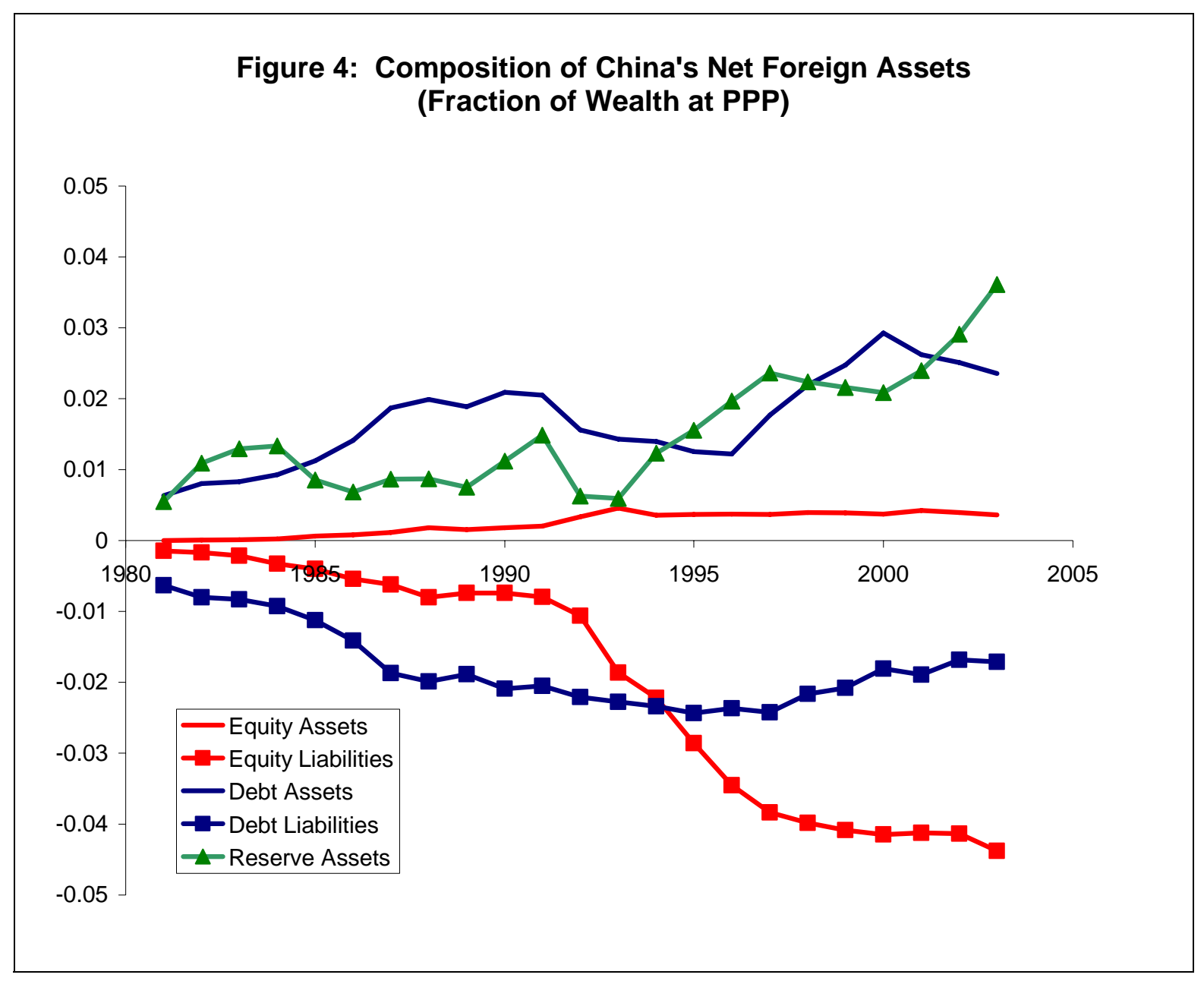


Figure 5: Foreign Assets and Capital Stocks Per Capita (Averages 1980-2000, 62 Countries)

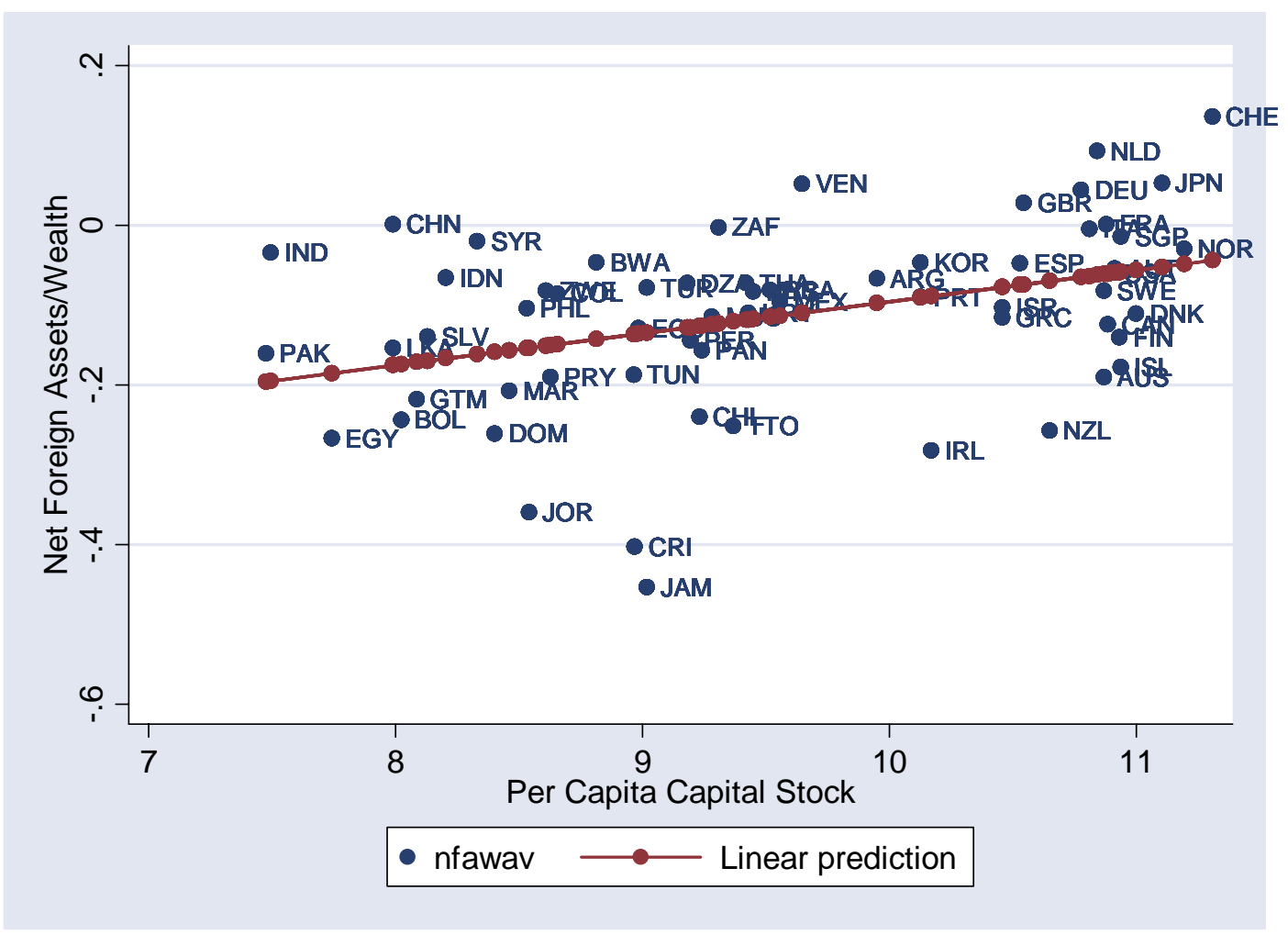


Figure 6: China's Net Foreign Asset Position: Sensitivity of Calibrations

Effect of Changes in ROW's Productivity Advantage

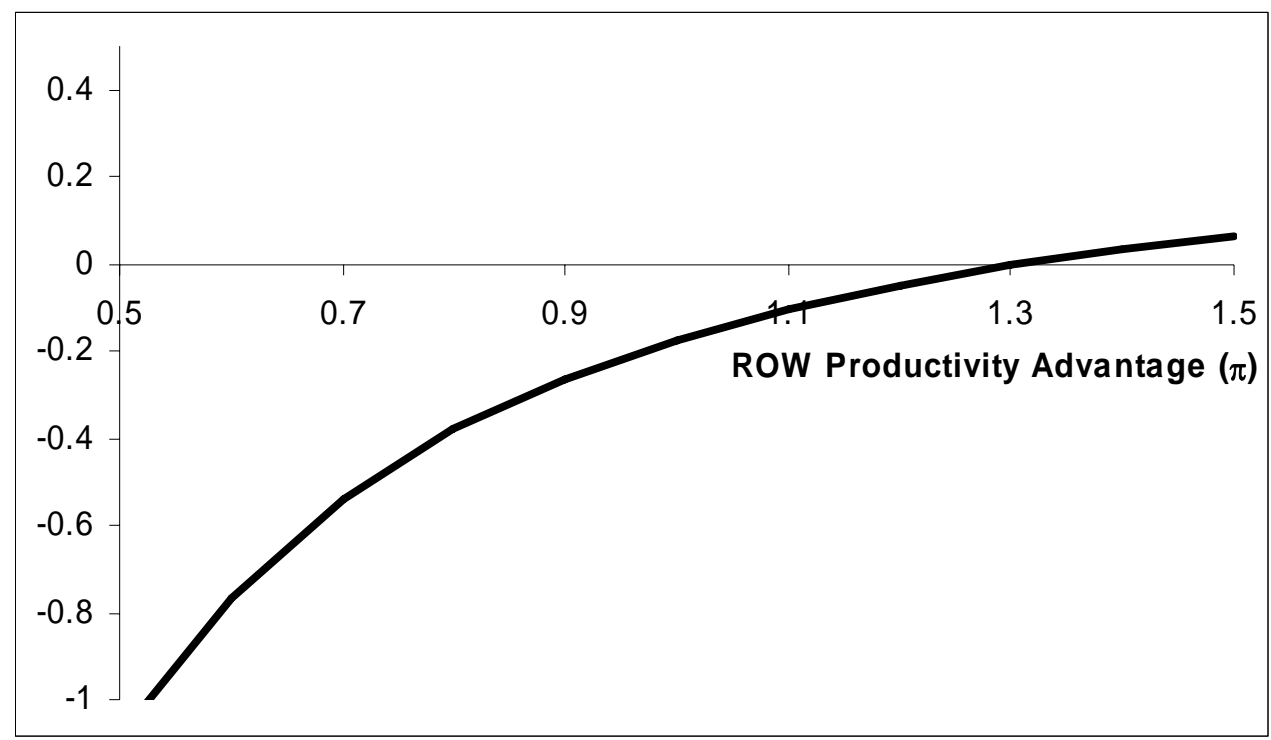

Effect of Changes in China's Relative Per Capita Wealth

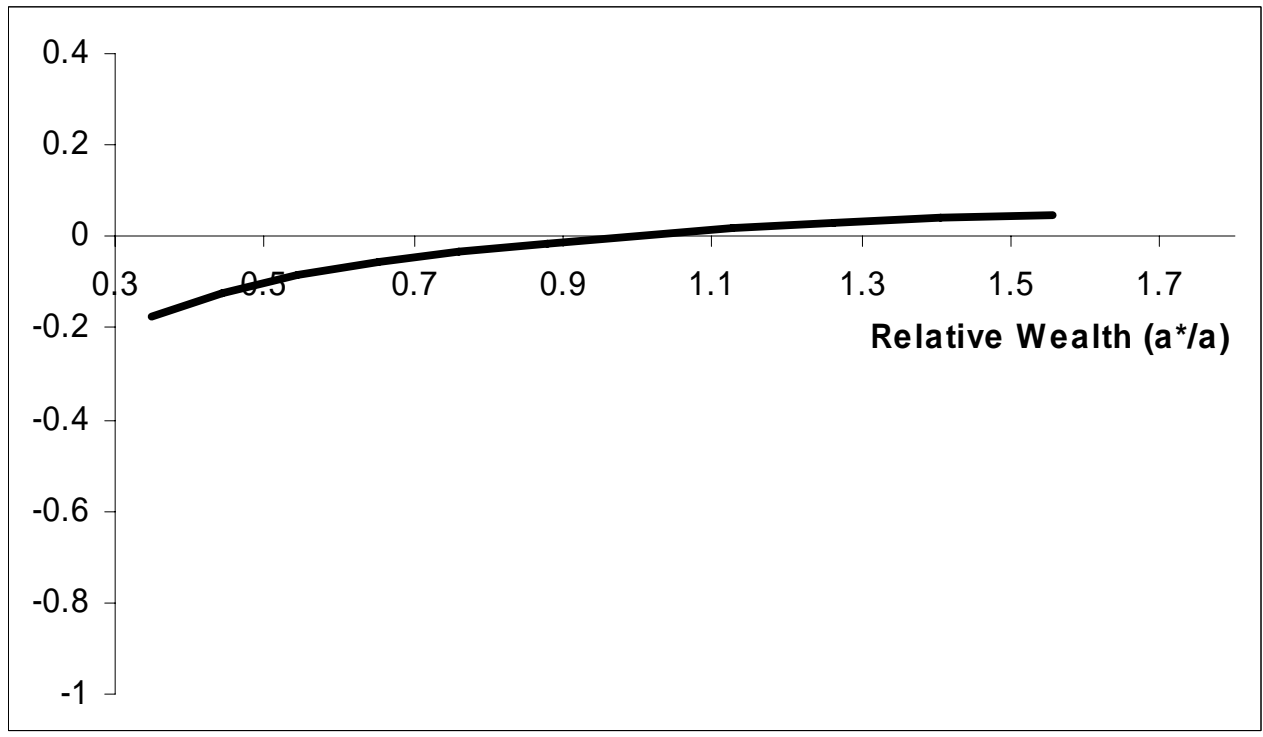


Figure 7: Relative Productivity and the Distribution of Factors of Production in Industry

Labour Productivity, Private Sector vs Overall Industry

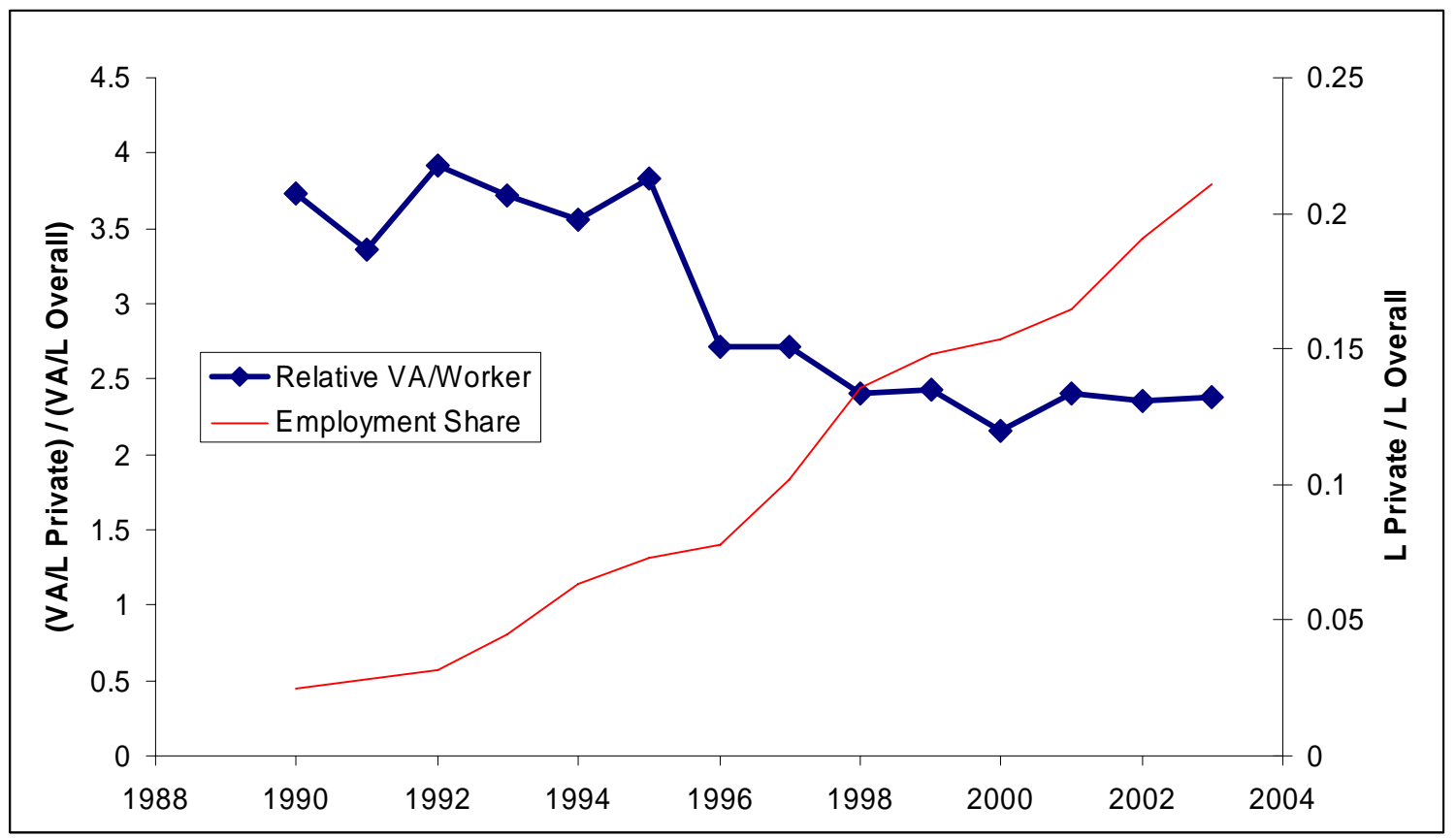

Capita Productivity, Private Sector vs Overall Industry

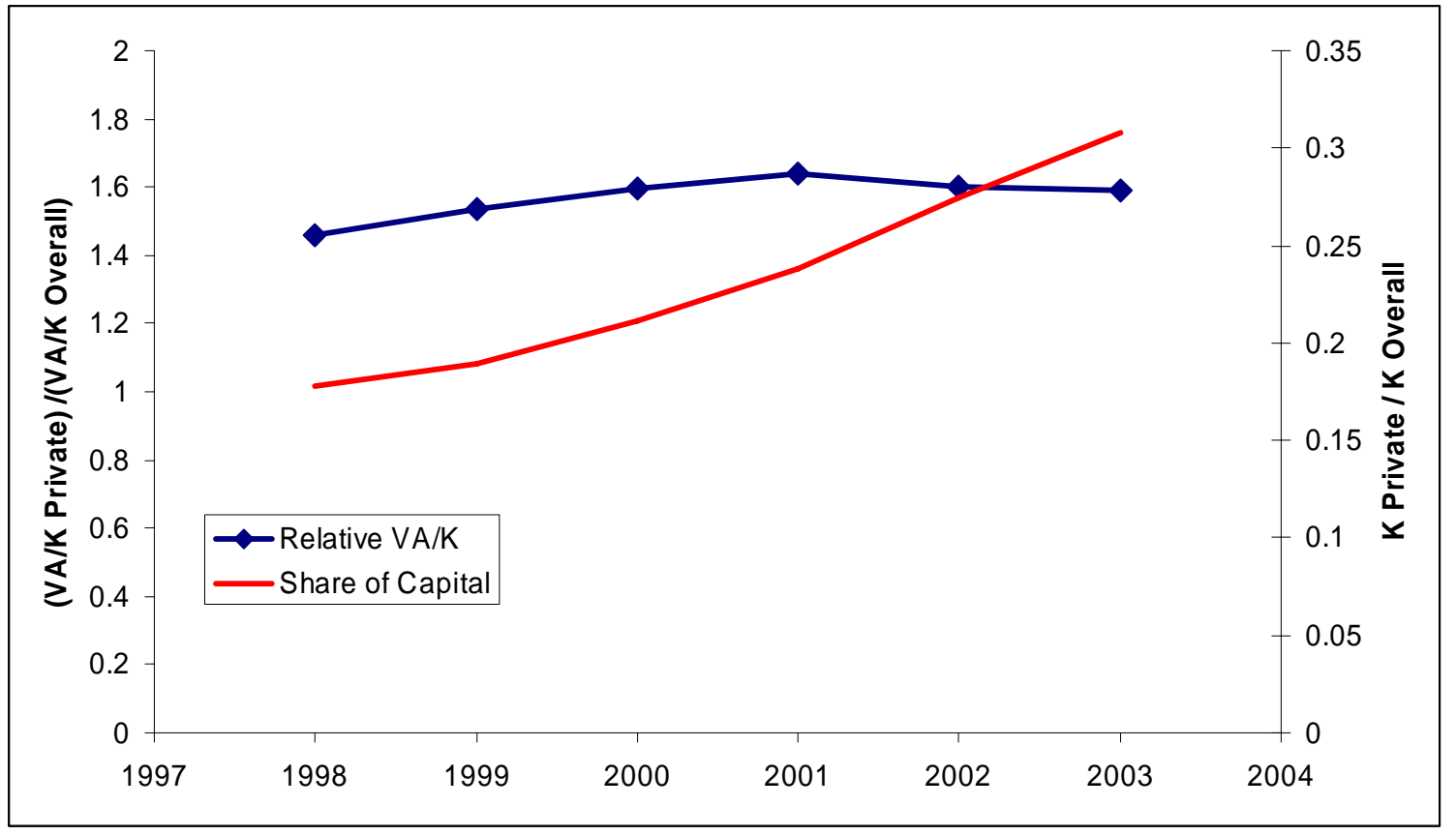

